\title{
Plant virus gene expression strategies
}

\author{
Pedro I. Bustamante ${ }^{1}$ \\ Laboratorio de Biotecnología, Universidad Mayor, Campus Huechuraba, Santiago-Chile, \\ E-mail: pbustama@risc.umayor.d \\ Roger Hull \\ John Innes Centre, Norfolk Research Park, Norwich, NR4 7UH, U.K. \\ E-mail: roger.hull@bbsrc.ac.uk
}

\begin{abstract}
Plant viruses can cause serious losses to most, if not all, major crops upon which depend for food. Many viruses are endemic, causing moderate losses each year. Others, such as those causing rice tungro, give periodic severe epidemics. There are no fully collated figures for world-wide losses due to viruses but some examples has been listed, i.e., rice tungro in SE ASIA and african cassava mosaic in Africa with 1,500 and 2,000 millions dollars per year in losses respectively.
\end{abstract}

However, in recent years the understanding of the genome organisation of plant viruses has increased in parallel with development of molecular biological techniques. The ability to obtain nucleotide sequences of complete viral genomes has also permitted the elucidation and understanding of expression strategies used by many different plant viruses. This review is aimed to summarise some aspects of the main strategies used by plant viruses to express their genomes.

To date the Virus Identification Data Exchange (VIDE) database (plant virus database operated at the Australian National University in Canberra, Australia) contains 569 characters for more than 890 plant virus species in 55 genera, according Gibbs (1994), and cited by Murphy et al. (1995). The VIDE database is accessible through the Internet from the BioWeb server http:/ / biology.anu.edu.au/ Groups/ MES/ vide/ (Brunt et al., 1996). Plant viruses can cause serious losses to most, if not all, major crops upon which we depend for food. Many viruses are endemic, causing moderate losses each year. Others, such as those causing rice tungro, give periodic severe epidemics. There are no fully collated figures for world-wide losses due to viruses but some examples has been listed by Hull (1994), i.e. rice tungro in SE Asia, african casava mosaic in A frica and potato viruses in UK with 1,500, 2,000 and 30-50 millions dollars per year in losses respectively.

In recent years the understanding of the genome organisation of plant viruses has increased rapidly in parallel with the development of molecular biological techniques. The ability to obtain nucleotide sequences of complete viral genomes has also permitted the elucidation and understanding of expression strategies used for many different plant viruses.

For many years, the only nudeic acid found in plant viruses was RNA, but it is now dear that viruses infecting plants may contain any one of the four types of genetic material: single-stranded RNA (ssRNA, about $75 \%$ of plant viruses), double-stranded RNA (dsRNA, reoviruses), single-stranded DNA (sSDNA, geminiviruses) or double-stranded DNA (dsDNA, caulimo- and badnaviruses). Of those for which the genome is known or can be extrapolated by being in the same group as a known virus, the vast majority have ssRNA of the $(+)$ or messenger polarity (termed $(+)$ RNA). These $(+)$ strand plant viruses are classified into more than 25 distinct taxonomic groups (Murphy et al., 1995) and show a wide variation in capsid morphology ranging from the rod shaped tobravirus, the filamentous potyvirus, to the icosahedral viruses (e.g. bromovirus, sobemovirus, comovirus, tombusvirus, nepovirus, tymovirus ).

There are also some economically important viruses with minus-strand and ambisense genomic RNA species (rhabdoviruses, tospoviruses and tenuiviruses). Tospovirus is the only genus of plant viruses in the Bunyaviridae family (German et al., 1992). However, Toriyama (1995) has also proposed to include the Tenuivirus group as a new genus of plant-related viruses of the Bunyaviridae family.

This review is aimed to summarise some aspects of the main strategies used by plant viruses to express their genomes.

\section{Genome organisation}

Although the majority of known plant viruses have RNA genomes, it is the smaller division of plant DNA viruses which are better known. In the following sections, mainly information related to plant RNA viruses will be discussed and for information about plant DNA viruses or some viroids, there are several reviews that cover in depth these aspects (Symons, 1991;Lazarowitz, 1992,Timmermans et al., 1994,Rothnie et al., 1994).

Plant RNA viruses show a wide variation in their genome structure and organisation and may have different terminal structures such as cap structures or genome-linked proteins (VPg) at the $5^{\prime}$ end and a poly(A)-tail or tRNA-like structure at the $3^{\prime}$ end of their RNA (reviewed by Goldbach et al., 1991). For some viruses the genome needed for infection is divided between two or more segments which may be encapsidated in the same partide or in separate particles (multicomponent) and even like the tobacco necrosis virus (TNV), have associated satellite RNAs (Hull, 1990; Hull and Davies, 1992, Matthews, 1991). Most, if not all, plant virus genomes encode four or more proteins with functions that operate at various stages in the infection cycle.

Information on the genome organisation and sequence similarities of the non-structural proteins, in particular of their RNA-dependent RNA polymerases (RdRps) and helicases, show that most plant RNA viruses are genetically related and appear to have possible evolutionary links with some animal RNA viruses (Ishihama and Barbier, 1994,Strauss et al., 1996).

\footnotetext{
${ }^{1}$ Corresponding author
} 
Table 1. Characteristic of RNA virus superfamilies

\begin{tabular}{|c|c|c|c|c|c|c|}
\hline Group & Lineage & Virus groups & $\begin{array}{l}\text { Helica } \\
\text { se } \\
\text { type }\end{array}$ & Common features & Morphology & $\begin{array}{l}\text { Hosts and } \\
\text { vectors }\end{array}$ \\
\hline $\begin{array}{c}\text { Super 1 (POL } \\
\text { 1) }\end{array}$ & $\begin{array}{l}\text { Picorna-like } \\
\text { Poty-like } \\
\text { Sobemo-like } \\
\text { Arteri-like }\end{array}$ & $\begin{array}{c}\text { Picornaviridae } \\
\text { Comovirus } \\
\text { Nepovirus } \\
\text { Calicivirus } \\
\text { Potyvirus } \\
\text { Bymovirus } \\
\text { Sobemovirus } \\
\text { Luteovirus } \\
\text { Nodavirus } \\
\text { Corona virus } \\
\text { Arterivirus } \\
\text { Torovirus }\end{array}$ & $\begin{array}{l}\text { III } \\
\text { None }\end{array}$ & $\begin{array}{c}5^{\prime} \text {-VPG } \\
\text { 3'-poli (A) } \\
\text { No subgenomic RNAs } \\
\text { Polyprotein processing } \\
\text { No overlapping ORFs } \\
\text { 5'-cap } \\
\text { 3'-poly (A) } \\
\text { Nested set of mRNAs } \\
\text { Enveloped }\end{array}$ & $\begin{array}{l}\text { Icosahedral } \\
\text { Separate } \\
\text { encapsidation } \\
\text { Rod-shaped } \\
\text { Isometric }\end{array}$ & $\begin{array}{l}\text { Mammals } \\
\text { Plants } \\
\text { Mammals } \\
\text { Plants } \\
\text { Plants } \\
\text { Insect } \\
\text { Mammals }\end{array}$ \\
\hline $\begin{array}{c}\text { Super } 2 \text { (POL } \\
\text { 2) }\end{array}$ & $\begin{array}{l}\text { Phage } \\
\text { Flavi-like } \\
\text { Pesti-like } \\
\text { Carmo-like }\end{array}$ & $\begin{array}{c}\text { RNA coliphages } \\
\text { Flavivirus } \\
\text { Pestivirus } \\
\text { Carmovirus } \\
\text { Tombusvirus }\end{array}$ & $\begin{array}{l}\text { None } \\
\text { II } \\
\text { II } \\
\text { None }\end{array}$ & $\begin{array}{c}\text { OneORF } \\
\text { No 3'-poly (A) }\end{array}$ & $\begin{array}{l}\text { Enveloped } \\
\text { Icosahedral }\end{array}$ & $\begin{array}{l}\text { Bacteria } \\
\text { Humans } \\
\text { Mammals } \\
\text { Plants }\end{array}$ \\
\hline $\begin{array}{c}\text { Super } 3 \text { (POL } \\
\text { 3) }\end{array}$ & $\begin{array}{c}\text { Tymo-like } \\
\text { Rubi-like } \\
\text { Tobamo-like }\end{array}$ & $\begin{array}{c}\text { Tymovirus } \\
\text { Carlavirus } \\
\text { Potexvirus } \\
\text { Capillovirus } \\
\text { Rubella } \\
\text { Hepatitis E } \\
\text { Alphaviruses } \\
\text { Tobamovirus } \\
\text { Tricornavirus } \\
\text { Hordeivirus } \\
\text { Tobravirus } \\
\text { Closterovirus }\end{array}$ & $\begin{array}{l}T \\
1\end{array}$ & $\begin{array}{c}5^{\prime} \text {-caps } \\
\text { Subgenomics mRNAs } \\
\text { No Overlapping ORFs } \\
\text { Readthrough (most) }\end{array}$ & $\begin{array}{l}\text { Tcosahedral } \\
\text { Filamentous } \\
\text { Enveloped } \\
\text { Rod-shaped }\end{array}$ & Plants \\
\hline $\begin{array}{c}\text { Minus strand } \\
\text { RNA } \\
\text { Paramyxovirida } \\
\text { e } \\
\text { Rhabdoviridae } \\
\text { Orthomyxovirid } \\
\text { ae } \\
\text { Arenaviridae } \\
\text { Filoviridae }\end{array}$ & & & & $\begin{array}{c}\text { Enveloped } \\
\text { Self-complementary } \\
\text { termini } \\
\text { Helical capsid } \\
\text { Overlapping ORFs }\end{array}$ & $\begin{array}{c}\text { Some } \\
\text { segmented } \\
\text { genomes } \\
\text { Somewith M } \\
\text { protein } \\
\text { Pleiomorphic } \\
\text { Enveloped rod }\end{array}$ & $\begin{array}{l}\text { Mammals } \\
\text { Birds } \\
\text { Fish } \\
\text { Insects } \\
\text { Plants }\end{array}$ \\
\hline $\begin{array}{c}\text { Double-strand } \\
\text { RNA } \\
\text { Reoviridae } \\
\text { Bimaviridae }\end{array}$ & & & & $\begin{array}{c}\text { Segmented genome } \\
\text { 5'-cap } \\
\text { 3'-OH } \\
\text { ss RNA intermediates }\end{array}$ & & $\begin{array}{l}\text { Vertebrates } \\
\text { Plants } \\
\text { Arthropods } \\
\text { Mollusks }\end{array}$ \\
\hline
\end{tabular}

Vpg, genome-linked protein; ORF, open reading frame Adapted from Straus et al., 1996

The analogous modular arrangement of these coding sequences also suggests that these viruses may employ similar RNA replication strategies (Dolja and Carrington, 1992; Koonin and Dolja, 1993). This has led to the proposal (Goldbach, 1986;Koonin, 1991a;Koonin et al., 1991;Dolja and Carrington, 1992;Koonin and Dolja, 1993), based on the three different types of sequence motifs in the RdRps, of the division of the positive-strand RNA viruses into three 'Supergroups'.

Supergroup I, which indudes, the Picorna-like, Poty-like, Sobemo-like and A rteri-like. They have common features as, a VPg protein covalently linked to the 5 ' end of the RNA, 3'poly (A), no subgenomic RNAs, polyprotein processing, no overlapping ORFs (see Table 1 for more detail).

Supergroup II, which includes the coliphages, Flavi-like, Pesti-like and Carmo-like viruses. They shares such features as, enveloped virions and no 3' -poly (A) (see Table 1).
Supergroup III, which includes the Tymo-like, Rubi-like and Tobamo-like viruses. They have common features as, 5 ' caps, subgenomics mRNAs, no overlapping ORFs and readthrough expression strategy (most of them) (see Table 1).

The grouping is based on sequence homology of three similarly organised non-structural proteins of Sindbis virus, including the RNA capping enzyme, RNA helicase and RdRp (Koonin, 1991a;Koonin, 1991b). Subgrouping can also be based on conserved sequence motifs of helicases (helicase superfamilies 1, 2 and 3), proteases and the presence of capping enzymes (reviewed in Koonin and Dolja, 1993). RdRp however is the only domain of positivestrand RNA viruses allowing an all-inclusive phylogenetic analysis.

\section{Replication of plant RNA viruses}


Most viruses encode proteins that are involved in viral nucleic acid replication. The discovery of the RdRps marked a major breakthrough in understanding the replication of progeny RNA from genomic viral RNA (reviewed in David et al., 1992; Ishihama and Barbier, 1994).

Potential RdRps have been described for many plant RNA viruses including brome mosaic virus (BMV) (Hardy et al., 1979), cowpea chlorotic mosaic virus (CCMV) (Miller and Hall, 1984), turnip yellow mosaic virus (TYMV) (Mouches et al., 1984), alfalfa mosaic virus (AIMV) (Houwing and Jaspers, 1986), cucumber mosaic virus (CMV) (Hayes and Buck, 1990), TMV (Young et al.., 1987), turnip crinkle virus (TCV) (Song and Simon, 1994), red clover necrotic mosaic dianthovirus (RCNMV) (Bates et al.., 1995), tomato spotted wilt virus (TSWV) (Adkins et al.., 1995). While it is accepted that the role of RdRp in replication of RNA viruses is essential, the mechanism of its function is undear and may differ for different virus groups. In in vitro studies on BMV, CCMV, AIMV, and TYMV the enzyme has only been shown to synthesise minus-strand RNA while complete replication of both minus-strand and new progeny plus-strand RNA has been demonstrated for CMV (Hayes and Buck, 1990).

In addition, host factors have also been implicated in the replication complexes of TYMV (Mouches et al.., 1984), TMV (Meshi et al.., 1988), cowpea mosaic virus (CPMV) (Derssers et al.., 1984), BMV (Quadt and Jaspars, 1990;Quadt et al., 1993), CMV (Hayes and Buck, 1990). The requirement for host-factors goes some way in explaining the inability of some extracted viral RdRps to fully complete a replication cycle. Proposed mechanisms for the precise mode of action of several viral RdRps as well as their structure and organisation have been reviewed extensively (for comprehensive reviews see Marsh et al., 1989,David et al., 1992,Ishihama and Barbier, 1994).

In general however, the viral RdRps are complex moieties, acting as RNA replicases or transcriptases, synthesising both $(-)$ and $(+)$ strands. Moreover, RdRps not only catalyse RNA polymerisation but, in many viruses, also effect RNA modifications (e.g. RNA methyltransferase activity).

\section{Replication of plus-strand RNA viruses}

Replication of plant positive-strand RNA viruses takes place in the cytoplasm of infected cells. RNA polymerases appear to be membrane-bound, and some proteins implicated in replication have membrane-binding domains, e.g. P58 encoded by RNA1 of CPMV. However the precise sites where RNA replication takes place have not been clearly defined and probably differ for different viruses. Granular inclusion bodies have been invoked as the sites for TMVRNA replication (Saito et al., 1987; Okamoto et al., 1988).

Replication of $(+)$ strand RNA viruses can be separated into four overlapping steps:(i) The uncoating of the virus, which exposes the nucleic acid to the replication processes. (ii) Translation, during which the viral RNA serves as a messenger RNA and produces structural and non-structural proteins. This process is further divided into the primary or early translation of proteins required for replication, e.g. the $\mathrm{RdRp}$, and secondary or late translation of proteins with late functions, e.g. the coat protein. (iii) Replication of the genome which yields progeny RNA molecules takes place in two stages, both catalysed by an RdRp:(1) Synthesis of a fulllength complementary (negative) RNA strand using the genomic (positive) RNA strand as a template (2) Synthesis of progeny genomic RNA and subgenomics RNAs using the negative-strand RNA as a template. And finally (iv) the progeny genomic strands are encapsidated.
The virus-encoded proteins required for RNA replication have been deduced from the composition of purified polymerases capable of copying genomic RNA to produce a negative strand, from the use of mutants, for divided genome viruses from the minimum number of RNA segments needed to infect protoplasts and from the presence of conserved sequence motifs found in polymerases in other systems (Quadt and Jaspars, 1990).

Initiation of the synthesis of a negativestrand on a positive strand RNA template requires binding of the polymerase to a recognition site at the $3^{\prime}$ end of the template. The $3^{\prime}$ end of the RNA of many viruses can be folded into a characteristic secondary or tertiary structure which includes the RNA polymerase binding site Sequences at the $5^{\prime}$ end of the genomic RNA are also required for RNA infectivity (French and Ahlquist, 1987) and presumably reflect the requirement for binding of the polymerase at the $3^{1}$ end of negative-strand RNA.

One system currently being used to study positive-strand RNA virus replication is the plant bromovirus group (A hlquist, 1992). The bromoviruses are icosahedral, positivestrand, tripartite RNA viruses in the alphavirus-like superfamily. The two bromovirus proteins required for RNA replication, $1 \mathrm{a}$ and $\mathrm{Za}$, are translated from genomic RNA 1 and RNA2, respectively, while proteins required for infection spread are translated from genomic RNA3 and a subgenomic mRNA, RNA4, transcribed from negative-strand RNA3. Protein la $(109 \mathrm{~K})$ contains an N-terminal $\mathrm{m}^{7} \mathrm{G}$ methyltransferase-like domain thought to be involved in capping viral RNA (Rozanov et al., 1992) and a C-terminal helicaselike domain (Gorbalenya et al., 1988). Protein 2a (94 K) contains a central polymerase-like domain (Kamer and A rgos, 1984). Site-specific mutagenesis studies showed that all three conserved domains in $1 \mathrm{a}$ and $2 \mathrm{a}$ are required for RN A synthesis (Kroner et al., 1990; Traynor et al., 1991).

Bromovirus RNA synthesis can be divided into three distinct steps:negativestrand synthesis, positive-strand synthesis, and subgenomic mRNA transcription. Each of these steps is differentially regulated. For example, negative-strand RNA accumulation plateaus by $8 \mathrm{~h}$ post-inoculation, while positivestrand genomic RNA and subgenomic mRNA continue to accumulate until or beyond $20 \mathrm{~h}$ post-inoculation (Kroner et al., 1990). French and Ahlquist (1987) described that BMV-directed replication of RNA3 in vivo depends on cis-acting sequences in three regions of RNA3:the $3^{\prime}$ and $5^{\prime}$ noncoding regions and the intercistronic noncoding region. Later, Janda and A hlquist (1993) demonstrated that BMV RNA3 derivates can be replicated and direct subgenomic mRNA transcription in yeast expressing BMV proteins la and 2 a from DNA plasmids.

Recently, it has been shown that yeast expressing 1a and 2a and replicating RNA3 derivatives can be extracted to yield BMV-specific templatedependent RdRp activity (Quadt et al., 1995). Moreover, even though RdRp activity was asssayed on in vitro-supplied BMV-RNA templates, it was found that RdRp can only be isolated from cels expressing certain BMV RNA template sequences as well as la and $2 \mathrm{a}$. Strong correlation between extracted RdRp activity and BMV (-)-strand RNA accumulation in vivo was found for all RNA3 derivatives tested. Thus, extractable in vitro RdRp activity paralleled formation of a complex capable of viral RNA synthesis in vivo. These results suggest that assembly of active $\mathrm{RdRp}$ requires not only viral proteins but also viral RNA, either to direct contribute some nontemplate function or to recruit essential host factors in the RdRp complex (Quadt et al., 1995) 
Zaccomer et al. (1995) have reviewed recently other elements believed to be involved in virus replication:

1) tRNA-like structures. It has long been known that the RNA genomes of certain positive-strand plant viruses have tRNA-related properties (reviewed in Mans et al., 1992). These 3 ' tRNA-like structures have been shown to be involved in minus-strand synthesis in the case of TMV (Dawson et al., 1988), BMV (Miller et al., 1985) and TYMV (Tsai and Dreher, 1991).

2) Pseudoknots. In addition to the pseudoknots in the tRNA-like structures, a few viruses have pseudoknots upstream of these structures which appear to participate in RNA replication. In TMV the most downstream of the six doublehelical structures that compose the three pseudoknots al ready mentioned located just upstream of the tRNA-like structure, is required for replication (Takamatsu et al., 1990). Also Leathers et al. (1993) have reported that this region probably is involved in translation. However, pseudoknots present either in BMV-RNA3 (Lahser et al., 1993) or TYMV (Tsai and Dreher, 1992) are only involved in RNA replication.

3) Poly(A) structures. In CPMV, both M-RNA and B-RNA contain the sequence UUUUAUU immediately followed by the poly(A) tail. This heptanucleotide sequence together with the first four $A$ residues immediately downstream can adopt a hairpin structure. A similar structure can also be formed by the M-RNA of RCMCV (Shanks et al., 1986). In CPMV B-RNA, deletions from the $3^{\prime}$ end of the RNA can prevent formation of the hairpin and dramatically interfere with RNA replication (Eggen et al., 1989).

4) Internal control region (ICR)-like sequences. Similarities exist between viral RNA sequences (bromoviruses, cucumoviruses, tobamoviruses, tobraviruses and tymoviruses) and the ICR2 of the RNA polymerase III promoter of eukaryotes (Marsh et al., 1989). A role for these sequences in replication has been demonstrated for BMV RNA (Pogue et al., 1992) and is also proposed for the RNA of CMV (Boccard and Baulcombe, 1993) and AIMV (van der Vossen et al., 1993). The presence of ICRlike sequences suggests that a host RNA polymerase III subunit and/ or one of its cofactors could participate in viral RNA replication.

\section{Replication of minus-strand RNA viruses}

Negativestrand RNA viruses are a large and diverse group of enveloped viruses. They are found in hosts from the plant and animal kingdoms, and have a wide range of morphologies, biological properties and genome organisations (Conzelmann, 1996). A major distinction is made between viruses whose genome consists of a single RNA molecule (order Mononegavirales), induding the families Rhabdoviridae, Paramyxoviridae and Filoviridae, and those possesing multipartite (segmented) genomes, comprising the families Orthomyxoviridae (six to nine segments), Bunyaviridae (three segments) and Arenaviridae (two segments).

Characteristically, the genetic information of negative-strand RNA viruses is exdusively found in the form of a ribonudeoprotein complex (RNP) in which the genomic or antigenomic SSRNA is tightly encapsidated in a nucleoprotein (N or NP) and associated with the virus RdRp. In the case of non-segmented viruses, the latter consists of a catalytic subunit (L) and a non-catalytic cofactor, a phosphoprotein $(P)$. After infection of a cell, the RNP serves as a template for two distinct RNA synthesis functions, transcription of subgenomic, usually non-overlapping
mRNAs and the replication of full-length RNAs (for detailed reviews see Galinski, 1991). The RNP genomes appear to posses only one promoter, at the $3^{\prime}$ end of the RNA where the virus RdRp enters for both mRNA transcription and genome replication (Conzelman, 1996).

For viruses in the family Bunyaviridae, the polymerase protein, either acting alone or in concert with undefined viral or cellular factors, must first functions as a cap-dependent endonuclease to generate a primer for transcriptions of a non-encapsidated transcript of subgenomic length. At some point, the polymerase must switch to a process of independently initiating transcription at the precise- $3^{\prime}$ end of the template and producing an encapsidated, full length transcript (Schmaljohn, 1996). Presumably, some viral or host factor is required to signal a suppression of the transcription termination signal responsible for generation of truncated mRNA and also to prevent the addition of the capped and methylated structures to the $5^{\prime}$ termini of the cRNAs (Schmaljohn, 1996). For the rhabdovirus vesicular stomatitis virus, the switch to antigenome synthesis appears to be controlled by the N protein (Banerjee, 1987).

In animal viruses such Influenza A (Orthomyxoviridae), which has a genome consisting of eight ssRNA segments of negative polarity, the replication and transcription of the virus genome are catalysed by a virus-encoded RdRp (Kobashagi et al., 1992, Huang et al., 1990). The RdRp is composed of three subunits, PB1, PB2 and PA, which are tightly associated at the doublestranded stem region of the panhandle formed by the $5^{\prime}$ and $3^{\prime}$ termini of each RNA segment (Huang et al., 1990, H su et al., 1987). RdRp plays an essential role in both replication and transcription but little is known about the molecular mechanism of replication. However, some evidence suggests that PBI, PA and the nucleoprotein can support the replication of the influenza virus genome as well as the transcription to yiedd uncapped poly (A)+RNA but PB2 is specifically required for the synthesis of capped RNA (Nakagawa et al., 1995).

Virion-associated RdRp polymerase activity has been also found in plant rhabdoviruses. In the case of wheat rosette stunt virus, both detergent-treated virions and isolated nudeocapsids exhibit RNA polymerase activity. Like animal rhabdoviruses, the enzyme activity can be regained upon mixing of $L$ and NS proteins and using $N$-associated RNA template. Products synthesised in vitro by the virionassociated RNA polymerase of plant rhabdoviruses contain genome-length and single-strand virus complementary RNA (vCRNA) indicating that the RdRp acts not only as transcriptase but also as replicase.

\section{Replication of ambisense viruses}

RdRp activity has been detected in detergent-disrupted virions of animal-infecting members of the Bunyaviridae (Vialat and Bouloy, 1992) and has been directly linked to the L-protein of bunyamwera virus, the type member of the family (Jin and Elliot, 1991). An RdRp activity has been found associated with virions of TSWV, a plant- and insectinfecting member of the family Bunyaviridae. Radiolabelled nucleoside triphosphate was incorporated into trichloroacetic acid-precipitable products by detergent-disrupted, purified TSWV virions. The predominantly double-stranded RNA products were RNase resistant at high but not low salt concentrations. Discrete products of approximately $3.0 \mathrm{~kb}$ were synthesised that hybridised to purified TSWV RNA and transcripts of CDNA clones encompassing parts of each of the three genomic RNAs. The predominant products were viral sense although significant amounts of viral complementary sense S RNA products were also synthesised (Adkins et al., 1995). 
Barbier et al. (1992) working with the Tenuivirus rice stripe virus (RSV) a virus with some genome organisation features in common with TSWV, isolated an RNA polymerase activity by $\mathrm{CsCl}$ centrifugation from purified RSV ribonucleoproteins (RNPs). The active fraction contained two viral structural proteins, a $30 \mathrm{~K}$ nucleocapsid $(\mathrm{N})$ protein and a $230 \mathrm{~K}$ putative polymerase protein. An in vitro RNA synthesis system was reconstituted using this RNA-free protein fraction and short model templates carrying the conserved $5^{\prime}$ and 3 ' terminal sequences. This showed that, as in the case of influenza virus, a minimum promoter function resides in the panhandle secondary structure formed by the complementary termini or in the 3' terminal sequence of 1114 nucleotides in length.

\section{Modes of gene expression}

Another major problem facing RNA viruses with limited genome size is their obvious dependence on the host eukaryotic protein-synthesising system. These small genomes are also expected to encode a range of virus proteins. The strategies of expression that have emerged from recent studies suggest that the viral genomes appear to have evolved to overcome the obvious constraints of the plant host system.

The eukaryotic 805 ribosome is usually able only to translate the first ORF in the $5^{\prime}$ region of an MRNA, according the "scanning ribosome model" proposed by Kozak (1991). The model states that the 405 ribosomal subunit (carrying MettRNA ime and various initiation factors) binds initially at the $5^{\prime}$ end of mRNA. The ubiquitous $\mathrm{M7G}$ cap and the associated cap-binding protein(s) explain the predilection of eukaryotic ribosomes to engage mRNA at the $5^{\prime}$-end. Then the migrating 405 ribosomal subunit stalls at the first AUG codon, which is recognised in large part by base pairing with the anticodon in Met-tRNAime. However, the stop-scanning step and hence selection of the initiator codon, is susceptible to modulation, by context, at least in vertebrates and selection of more distal AUG is permitted under certain defined circumstances (Kozak, 1991).

The possibility that might be cases of internal translation initiation has been shown. Pelletier and Sonenberg (1988) have proposed that there is efficient internal initiation on poliovirus RNA. The evidence comes from experiments exploiting the fact that translation of a dicistronic mRNA with two non-overlapping ORFs ( $A$ and $B$ ) generally gives a low yield of B protein (located downstream) compared with A.

Pelletier and Sonenberg (1988) used a construct in which the entire 5 ' untranslated region (736 nt) of type 2 poliovirus was placed in the intercistronic region of a capped dicistronic mRNA. When the cells expressing the dicistronic mRNA are infected with the poliovirus, the synthesis of protein $A$ (upstream) was inhibited and protein B enhanced, demonstrating that downstream cistron translation is independent of upstream. In addition, cell-free extracts from poliovirus-infected cells translated cistron B but not $A$. Similar results have been published also by Jang et al. (1988) for encephalomyocarditis virus RNA and more recently for bovine viral diarrhea virus by Poole et al. (1995).

The main strategies used by plant viruses to allow protein synthesis in a eukaryotic system from positive sense RNA genome containing more than one gene are discussed below (see Figure 1 for some illustrations).

\section{Subgenomic RNAs}

The expression of internal genes such coat protein (CP) of the positive RNA viruses is frequently mediated via subgenomic RNAs, considered in this study as mRNAs (see Figure 1a). These mRNAs are encapsidated in some viruses, but not in others. Among plant RNA viruses, the mechanism of synthesis of the subgenomic RNA encoding the CP has been examined in several viruses, i.e., TMV (Palukaitis et al., 1983), CMV (Jaspars et al., 1985). From these studies, two mechanisms have been proposed to explain the synthesis of subgenomic RNA species:(1) During (-) RNA strand synthesis by the RdRp, premature termination could lead to the formation of (-) RNA strands of subgenomic length that could serve as template to generate the subgenomic (+) RNA; alternatively (2) the subgenomic (+) RNA could be synthesised via internal initiation on (-) RNA strands of genomic length.

The evidence from in vivo and in vitro experiments with various RNA viruses clearly tends to favour the second mechanism. Since subgenomic RNAs contain at their $3^{\prime}$ end the elements required for the production of complementary subgenomic RNA chains, various explanations have been put forward to account for the lack of autonomous replication of subgenomic RNA. These are that (1) the sequence contained within the subgenomic RNA is insufficient for replication of the subgenomic RNA; (2) the subgenomic RNA, which is frequently a highly efficient mRNA, may not be available for replication; and (3) the subgenomic RNA would be produced late in infection or at time when negative-strand synthesis has ceased. From different experiments, the first explanation is certainly the most likely.

Miller et al. (1985), studying the mechanism of BMV subgenomic RNA4 formation from genomic RNA3 by using the in vitro RdRp system provided, the first unequivocal evidence that the subgenomic RNA of a positive-strand RNA virus is synthesised (at least in vitro) by internal initiation of positive-strand RNA synthesis on a negative-strand template. 
Gentrontic IRAA $6,395 \mathrm{mt}$
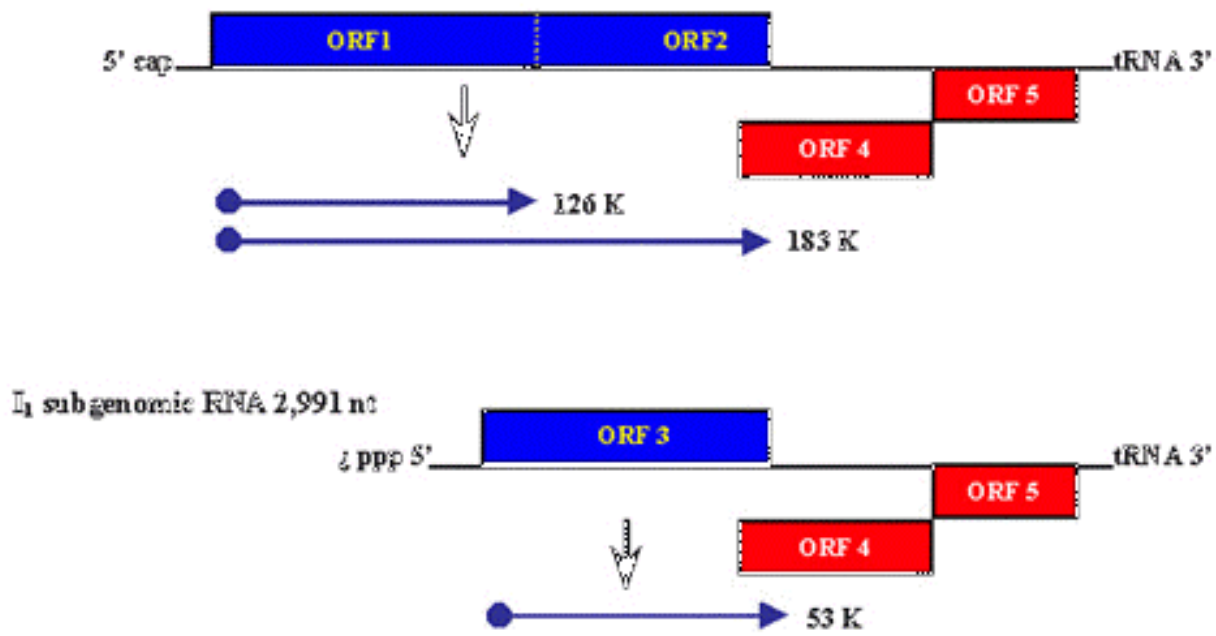

$\mathbb{I}_{2}$ ssbgen om: $\mathrm{RNA} \mathbb{1}, 500 \mathrm{nt}$

PFP ${ }^{3}$ $\triangle R N A 3^{\circ}$

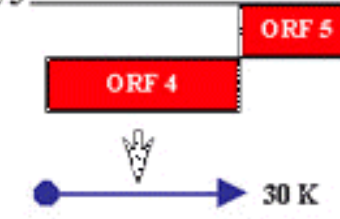

Ceet protein sub genomic RITA ES2 328

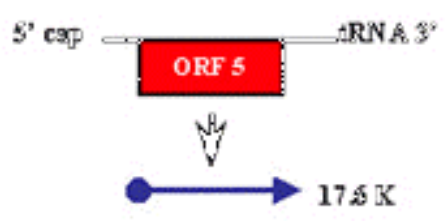

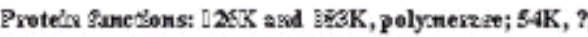

$30 \mathrm{~K}$, ceil te cell moremsant; $37.6 \mathrm{~K}$, coat F rotals.

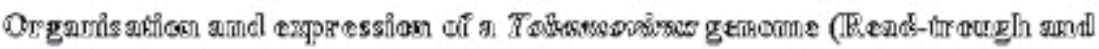

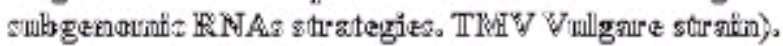

Figure 1a.

The internal promoter involved in RNA4 synthesis was identified using an altered negative-RNA3 strand as template (Miller et al., 1985; Marsh et al., 1986). Deletions 3 ' from the RNA4-corresponding sequence were performed on the RNA3 negative-strand to identify the core sequence required for initiation of positive-RNA4 synthesis. They are located, respectively, 20 nudeotides downstream from the RNA4 start site and 17 nudeotides into the RNA 4 sequence.

An oligo (U) region $3^{\prime}$ from this negativestrand core promoter sequence seems to function as a spacer, ensuring accessibility of the promoter for the viral RdRp, since its removal leads to an important decrease in RNA4 synthesis (Marsh et al., 1986).

Further studies have been performed to investigate the nature and behaviour of sequences influencing RNA4 production in vivo. The roles of additional downstream sequences and positional effects on promoter functions have also been studied (Allison et al., 1988). Four regions can be identified as playing a role in RNA4 initiation in vivo. 
First, as demonstrated in vitro, initiation of subgenomic RNA synthesis does not require more than 17 nudeotides of the RNA4 sequence (nucleotides +1 to +17 ). Second, sequences $3^{\prime}$ from the start site of RNA4 can be divided into three different domains. They correspond to the 20 nucleotides upstream (nucleotide -1 to -20), an oligo(U) stretch (nucleotides -20 to -38) downstream from this region, and finally, an $(A+U)$ rich sequence (nudeotides -38 to -95 ) adjacent to the oligo (U). The region containing the first two domains contributes favouring correct initiation of positive RNA synthesis. The entire promoter sequence is 112 nucleotides long.

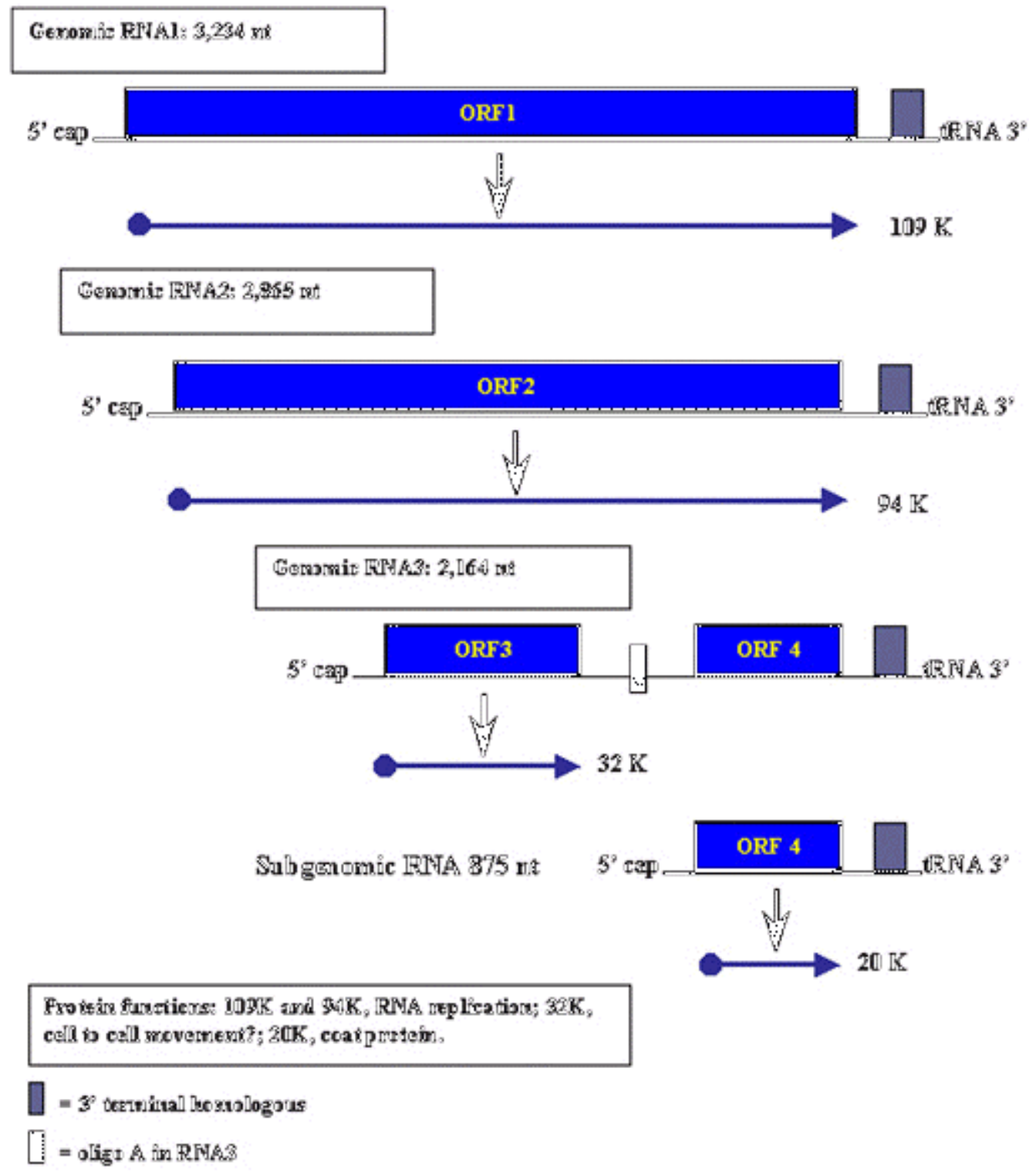

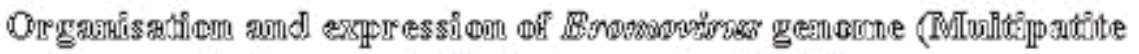

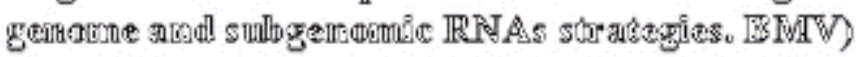

Figure 1b.

For TMV, however, two separate subgenomic promoter sites have been identified in the negative-strand, which control synthesis of the mRNAs for P30 (expressed relatively early) and CP (expressed late) (Young et al.,1985; Lehto and Dawson, 1990).
For the expression of ambisense viruses several lines of evidence indicate that subgenomic mRNAs are formed from each RNA strand, and full-length vRNA and genome-size vcRNA are synthesised only during replication. For several animal-infecting members of the Bunyaviridae the process of initiation and termination of transcription has been further 
studied by characterising the $5^{\prime}$ and $3^{\prime}$ ends of viral mRNAs (reviewed by German et al., 1992).

These studies have shown the presence of short heterogeneous non-viral sequences at the $5^{\prime}$ ends of the mRNAs, indicating that the viral transcriptase uses RNA primers to initiate transcription (Bishop et al., 1983;Bouloy et al.,1990;Simons and Pettersson, 1991; Gro et al., 1992; Jin and Elliot, 1993). These primers are generated from capped host messenger RNA species by a process referred to as "capsnatching", i.e. the 5' terminal sequence of a cellular mRNA is deaved off by an endonudease and subsequently used to initiate transcription on the viral genome (Braam et al., 1983; Ulmanen et al., 1981). Less is known about the termination of transcription, but some typical structures features, e.g., palindromic sequences or hairpin structures, have been found close to the site where termination occurs (Bouloy et al., 1990; Simons and Pettersson, 1991).

The first report of a plant virus using such a mechanism for transcription of the viral genome was described for TSWV by Kormelink et al. (1992). Subgenomic mRNAs for the S RNA segment were partially purified from total RNA extracts of TSWV-infected Nicotiana rustica and analysed by primer extension analysis. Recently, Bustamante (1996) studied the expression strategy used by a related virus, the Tenuivirus rice hoja blanca virus (RHBV) and found that both the $\mathrm{N}$ and NS3 subgenomic RNAs overlaped at their 3 ' end sequences (see Figure 2). Only in the phlebovirus Uukuniemi virus a similar expression strategy has been described (Simmons and Pettersson, 1991). The 3 ' termini of both $\mathrm{N}$ and NS3 subgenomic RNAs were predicted to have a "poly (A)like" sequence. This was confirmed when oligo d(T) magnetic beads were used to isolate the subgenomic RNAs species from both total RNA from infected plants and from viral RNA samples. The extraction of subgenomic RNAs species from total RNA and viral RNAs samples was obtained using biotinylated primers, specifically designed from within the coding sequence of the N and NS3 proteins (Bustamante, 1996). These results suggests that subgenomic RNA species are genuinely "encapsidated" or associated with N proteins and therefore may be translated very early during the viral cycle. Perhaps the $\mathrm{N}$ protein is not a late protein in the viral cycle of RHBV as has been suggested for RSV N protein. Hamamatsu et al. (1993) has suggested that protein encoded in the vc-sense of RSV should be expressed late in viral cycle, after the transcription has been completed, in contrast to the protein encoded in the $5^{\prime}$ end of ambisense RNA species. On the other hand, Ramirez et al., (1995) have showed the presence of non-viral sequences, $12-20$ nucleotides in length, at the $5^{\prime}$ ends of the $\mathrm{N}$ and NSs mRNAs of RHBV-RNA4.

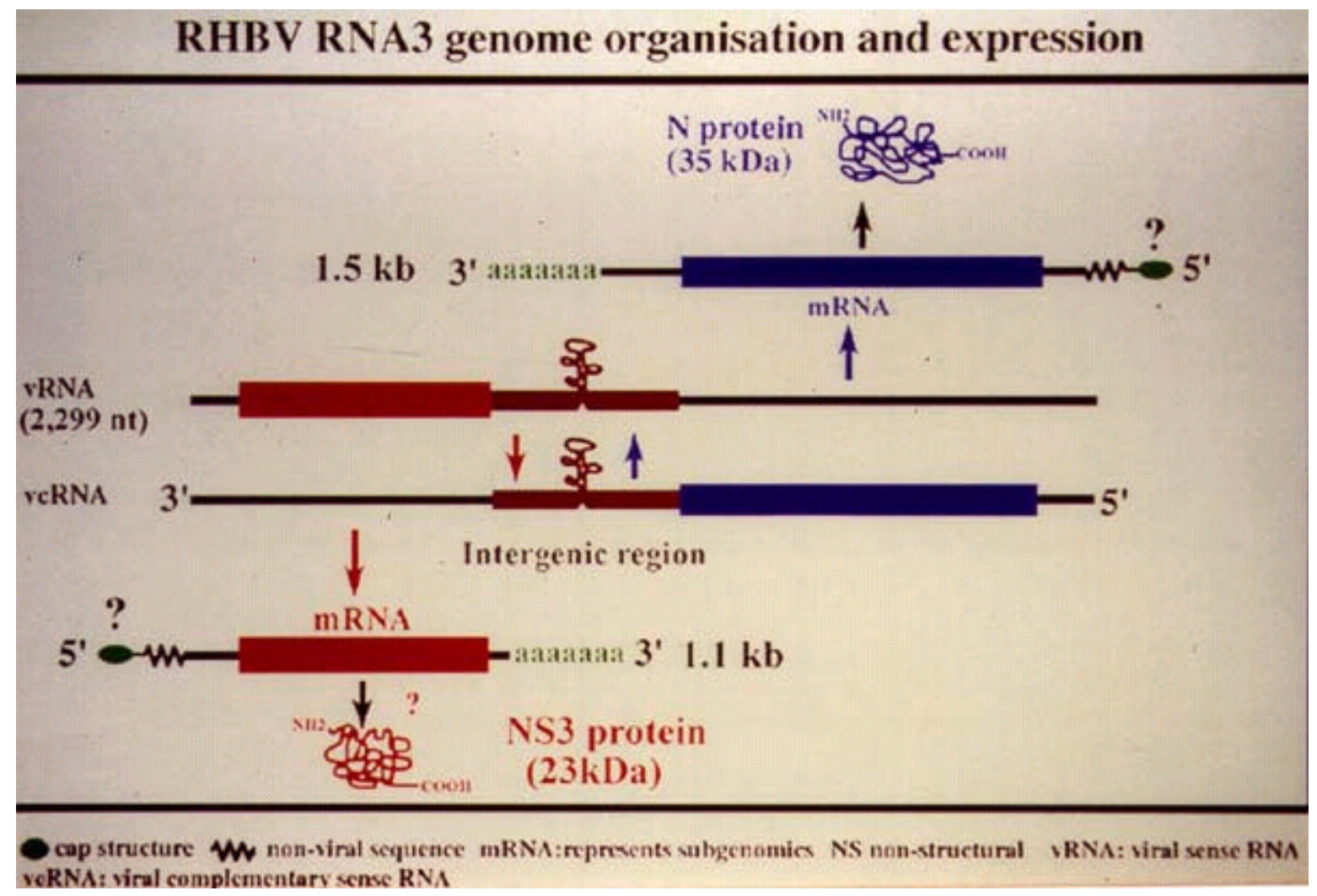

\section{Multipartite genome}

Division of the genome into more than one segment can result in monocistronic RNAs (see Figure 1b). For example, the genome of BMV consists of three RNA segments, of which RNA1 and 2 contain a single cistron (A hlquist et al., 1984). Other viruses such as CMV and AIMV are similar in this respect. RCNMV has two RNA segments, of which RNA 2 is monocistronic (Lommel et al., 1988)

\section{Polyprotein}

In this strategy the viral genome contains a long ORF which is translated and then deaved into smaller, functional proteins by viral proteinases (Goldbach, 1990). Since these proteinases form part of the polyprotein, initial cleavages should be autocatalytic (see Figure 1c).

The potyvirus group is one of the most important groups of plant viruses and members characteristically express their genome through a polyprotein process. The potyviral 
genome is approximately $10 \mathrm{~kb}$ in length and encodes a single polyprotein that is processed by three viral proteinases to yiedd nine or more mature proteins (Riechmann et al., 1992). Two of the proteinases, $P 1$ and helper componentproteinase (HC-Pro), each catalyse deavage only at their respective C termini (Verchot et al., 1991). The remaining deavage sites (at least six) are processed by the Nla proteinase, a homologue of the picornaviral $3 C$ proteinase. This enzyme possesses a serinetype proteinase fold but contains a nucleophilic Cys residue rather than Ser at the active site (Gorbalenya et al., 1989).

The best known members of the group are tobacco etch virus (TEV) and potato $Y$ virus (PVY). At present most is known about the gene products of TEV and their expression. Thus, the following sections deal mainly with this virus. The main features of the TEV genome are:(i) a VPg is attached to the $5^{\prime}$ end. (ii) a 5' non-coding region of $144 \mathrm{nt}$ rich in A and U; (iii) a single large ORF of 9161 nt initiating at residue 145-147, which could encode for a polyprotein with about 3000 amino acids (about $340 \mathrm{~K}$ ); and (iv) a 3' untranslated region of 190 bases terminating in a poly $(A)$ tract.

In the case of TEV the specificity of NIa is mediated by interaction between a binding site pocket around the active site and a heptapeptide motif, consisting of strictly and structurally conserved residues between the P6 and P1 positions of the cleavage site (Dougherty et al., 1989). Results of in vitro experiments indicate that processing sites flanking the $6 \mathrm{~K}$ protein and Nla are deaved preferentially in cis, whereas other sites are processed efficiently in trans (Carrington and Dougherty, 1988).

The $49 \mathrm{~K}$ N Ia protein is actually a polyprotein consisting of a proteinase domain $(27 \mathrm{~K}$ ) near the $\mathrm{C}$ terminus and a VPg (21 K) near the amino terminus (Dougherty and Parks, 1991). The VPg domain is attached covalently to the 5 terminus of viral RNA via a phosphodiester linkage with Tyr-62 (Murphy et al., 1990). The N-terminal domain also contains a nudear localisation signal that directs the majority of Nla molecules to the nucleus of infected cells (Carrington et al., 1991)

contain conserved Tyr and GIn residues at the P3 and P1 positions, respectively, the internal Nla site contains Thr and Glu (Dougherty and Parks, 1991).

\section{Read-through protein}

The first cistron in the genomic viral RNA may have a "leaky" termination codon (UAG or a UGA) that can be suppressed by a host transfer RNA (tRNA), thereby permitting some of the ribosomes to read through into a downstream cistron as a result, giving rise a second longer functional polypeptide (see Figure la, Figure 1d.).

For the tobamoviruses, tobraviruses, tombusviruses, carmoviruses and for RNA1 of soilborne wheat mosaic furovirus (SBWMV), this read-through process allows synthesis of the putative polymerase, and for RNA2 of SBWMV, RNA1 of pea enation mosaic virus and the luteoviruses, the termination codon of the capsid protein gene is overcome to allow synthesis of a longer protein involved in transmission, virus assembly or other functions (Zaccomer et al., 1995).

For the tobamoviruses, tobraviruses, tombusviruses, carmoviruses and for RNA1 of soilborne wheat mosaic furovirus (SBWMV), this read-through process allows synthesis of the putative polymerase, and for RNA2 of SBWMV, RNA1 of pea enation mosaic virus and the luteoviruses, the termination codon of the capsid protein gene is overcome to allow synthesis of a longer protein involved in transmission, virus assembly or other functions (Zaccomer et al., 1995).

The read-through process requires at least two elements. First, a suppressor tRNA; the nature of a possible candidate has been proposed for TMV (Beier et al., 1984;Zerfass and Beier, 1992a) and for tobacco rattle tobravirus (Zerfass and Beier, 1992b). Second, the nucleotide context surrounding the termination codon and in particular the two downstream codons appear important for readthrough of TMV RNA in vivo (Skuzeski et al., 1991) and in vitro (Valle et al., 1992)

\section{Translational frameshift}

Ribosomal frameshifting is a strategy frequently employed by various organisms to produce more than one protein from overlapping reading frames. It may occur in either direction. A shift in the 3 ' direction ( +1 frameshift) has been described in the yeast retrotransposon Ty (Belcourt and Farabaugh, 1990), whereas a shift in the $5^{\prime}$ direction (-1 frameshift) has been demostrated for retroviruses (Vickers and Ecker, 1992) luteoviruses (Prufer et al., 1992;García et al., 1993) and RCN MV (Xiong et al., 1993).

For a number of retroviruses, heptanudeotide signals are involved as "slippery sequences" in the frameshift. These include the sequences AAAAAAC (mouse mammary tumour virus); AAAUUUA (Rous sarcoma virus) and UUUUUUA (human immunoeficiency virus) which allow for tRNA slippage during translation (Hatfield et al., 1989). In addition to the specific sequence signal a second type of information bears relevance to frameshifting (Hatfield and Oroszlan, 1990): stem-loop structures immediately downstream of the "slippery sequences" have significant influence on the efficiency of the frameshift event.

Among plant RNA viruses, the RdRp of potato leafroll luteovirus (PLRV) is expressed by -1 ribosomal frameshifting in the region where the ORFs of the proteins $2 a$ and $2 b$ overlap. The viral genome of PLRV consists of $5.8 \mathrm{~kb}$ singlestranded (+) RNA with six major ORFs (Mayo et al., 1989; Van der Wilk et al., 1989; Keese et al., 1990). An intergenic region located in the centre of the RNA genome separates a $5^{\prime}$ duster of genes (ORFs $1,2 \mathrm{a}$ and $2 \mathrm{~b}$ ), which are divergent among the luteoviruses sequenced so far, from a highly conserved gene block (ORFs 3,4 and 5) in the 3' half. In the $5^{\prime}$ half of genomic PLRV RNA the small ORF1 is followed by two large ORFs, ORF2a and ORF2b, which may code for a $70 \mathrm{~K}$ and a $67 \mathrm{~K}$ protein, respectively, and contain the motifs characteristic of helicases (ORF2a and ORF2b; Habili and Symons, 1989) and GDD (ORF2b; Kamer an Argos, 1984).

The signal responsible for efficient frameshift in PLRV is composed of the slippery sequence UUUAAAU followed by a sequence that has the potential to adopt two alternative folding patterns, either a structure involving a pseudoknot, or a simple stem-loop structure. Kujawa et al. (1993) have confirmed that in PLRV-P (Polish isolate) the - 1 frameshift in the overlap region depends on the slippery site and on the downstream positioned sequence a proposed pseudoknot is required for efficient frameshifting. These results are in agreement with those reported for beet western yellows luteovirus by García et al. (1993). 


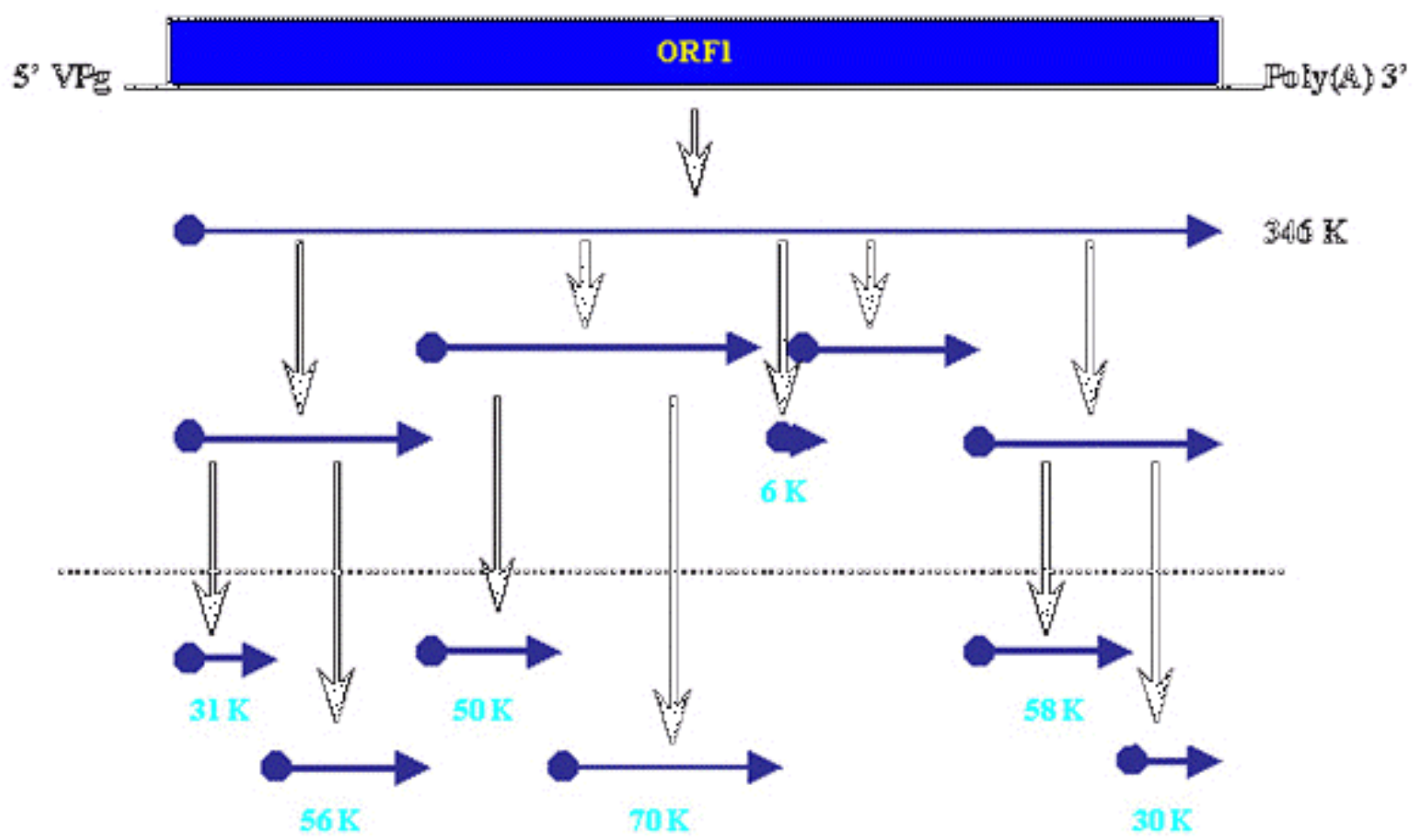

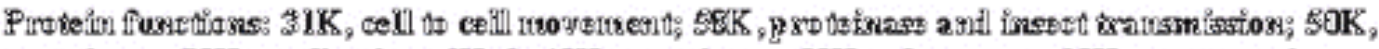

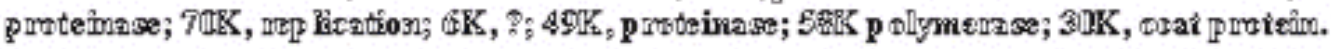

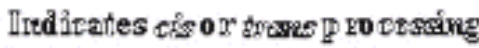

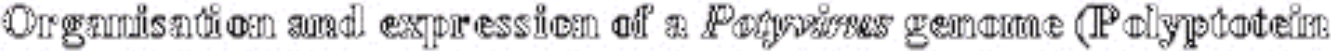 sinogitegy, TEV)}

Figure 1c.

Frameshifting has also been postulated as an expression strategy of PEMV RNA2 (Demler et al., 1993). Moreover, in beet yellows virus, a unique case among viruses of +1 frameshift has also been proposed (Agranovsky et al., 1994).

\section{Use of bicistronic RNAs}

A mechanism whereby the $5^{\prime}$ cistron was bypassed by ribosomes has been suggested for Agronowski (1991), cited by Hull (1992), for the expression of the beet yellows closterovirus 65-K cistron, which is downstream of a 6.4-K cistron. The latter cistron has no internal AUG codons in any of the reading frames, from where the expression of the 65-K cistron could be initiated. Recently, Grieco et al. (1995) has reported the presence of a bicistronic RNA from the olive latent virus 2. However, the RNA3 of the virus contains two clear-cut ORFs in same reading frame The encapsidation at a very low level, of an RNA species (smaller by about $350 \mathrm{nt}$ 
and denominated RNA 4) with a very high sequence homology with the RNA3, could explain the expression of the second ORF.

Three other mechanisms will be briefly mentioned here to explain the expression strategies used by caulimoflower mosaic virus (CaMV), a dsDNA virus that, to express the different cistrons, transcribes their genome into two RNA species, the polycistronic 35S and the monocistronic 195 (Rothnie et al., 1994; Kiss-Laszlo et al., 1995).

1.- "Ribosome shunt". Studies carried out to analyse the translation of the CaMV in protoplasts suggested a mechanism by which ribosomes enter at the cap site as normal and begin scanning. But at some point near the $5^{\prime}$ end of the leader, they are somehow transferred to a region at the $3^{\prime}$ end of the leader, without scanning linearly through the central portion of the leader. This process has been termed "ribosome shunt" and the sites between which it occurs have been defined (Futterer et al., 1993).

The shunt mechanism has been observed to operate between two separate RNA molecules, thus reinforcing the fact that the ribosomes are transferred directly from one part of the leader to another without scanning the sequence in between (Rothnieet al., 1994).

2.- "Translational trans-activation". Translation of downstream ORFs on the polycistronic RNAs of caulimoviruses depends on the presence of a virally encoded translational trans-activator (TAV), which is the product of ORF VI. TAV is a complex protein that appears to be involved in many aspects of the virus life cycle (De Tapia et al., 1993 ). It has been shown to be part of abundant vacuolated inclusion bodies as well as determinant of host specificity and a factor influencing symptom development in infected plants (Broglio, 1995; De Tapia et al., 1993). As mention above, another of its role is to control translation from the polycistronic CaMV $35 \mathrm{~S}$ RNA. Translational transactivation has been demonstrated for CaMV and figwort mosaic virus (Bonneville et al., 1989; Gowda et al., 1989) and appears to enhance expression of all the majors ORFs on the pregenomic 35S RNA (Scholthof et al., 1992). The TAV is itself translated from the 19S RNA, but can probably also trans-activated its own expression from ORF VI on the 355 RNA (Driesen et al., 1993). Like the "ribosome shunt", transactivation seems to act on ribosomes that have begun scanning of the RNA at the $5^{\prime}$ end. The process of transactivation seems to allow ribosomes that have translated one ORF to remain competent to translate further downstream ORFS, or to become initiation competent once more (Rothnie et al., 1994).

3.- "Splicing". It was previously though that there was no obligate role for splicing in either plant or animal pararetroviruses. However, the finding of splicing in rice tungro bacilliform virus was the first case to break this rule (Futterer, 1994). More recently, Kiss-Laszlo et al. (1995) have described the detection of spliced CaMV RNAs in infected plants and transfected protoplasts. Transient expression experiments revealed a splice donor site in the leader sequence of CaMV $35 \mathrm{~S}$ RNA and three additional splice donor sites within ORF I. Splicing between the leader and ORF II produces an MRNA from which ORF III and, in the presence of TAV, ORF IV can be translated efficiently. The other three splicing events produce RNA s encoding ORF I-II in frame fusions. All four spliced CaMV RNAs were detected in CaMV-infected plants. Virus mutants in which the splice acceptor site in ORF II is inactivated are not infectious, indicating that splicing plays as essential role in the CaMV lifecycle.
These different strategies described above can be used exclusively, or, as a combination of strategies for a particular virus.

The first report of a plant virus using such a mechanism for transcription of the viral genome was described for TSWV by Kormelink et al. (1992). Subgenomic mRNAs for the S RNA segment were partially purified from total RNA extracts of TSWV-infected Nicotiana rustica and analysed by primer extension analysis. Recently, Bustamante (1996) studied the expression strategy used by a related virus, the Tenuivirus rice hoja blanca virus (RHBV) and found that both the $\mathrm{N}$ and NS3 subgenomic RNAs overlaped at their 3 ' end sequences (see Figure 2). Only in the phlebovirus Uukuniemi virus a similar expression strategy has been described (Simmons and Pettersson, 1991). The 3 ' termini of both N and NS3 subgenomic RNAs were predicted to have a "poly (A)like" sequence. This was confirmed when oligo d(T) magnetic beads were used to isolate the subgenomic RNAs species from both total RNA from infected plants and from viral RNA samples. The extraction of subgenomic RNAs species from total RNA and viral RNAs samples was obtained using biotinylated primers, specifically designed from within the coding sequence of the N and NS3 proteins (Bustamante, 1996). These results suggests that subgenomic RN A species are genuinely "encapsidated" or associated with $\mathrm{N}$ proteins and therefore may be translated very early during the viral cycle. Perhaps the $\mathrm{N}$ protein is not a late protein in the viral cycle of RHBV as has been suggested for RSV N protein. Hamamatsu et al. (1993) has suggested that protein encoded in the vc-sense of RSV should be expressed late in viral cyde, after the transcription has been completed, in contrast to the protein encoded in the $5^{\prime}$ end of ambisense RNA species. On the other hand, Ramirez et al., (1995) have showed the presence of non-viral sequences, 12-20 nucleotides in length, at the $5^{\prime}$ ends of the N and NSs mRNAs of RHBV-RNA4.

\section{Multipartite genome}

Division of the genome into more than one segment can result in monocistronic RNAs (see Figure $1 b$ ). For example, the genome of BMV consists of three RNA segments, of which RNA1 and 2 contain a single cistron (Ahlquist et al., 1984). Other viruses such as CMV and AIMV are similar in this respect. RCNMV has two RNA segments, of which RNA2 is monocistronic (Lommel et al., 1988)

\section{Polyprotein}

In this strategy the viral genome contains a long ORF which is translated and then cleaved into smaller, functional proteins by viral proteinases (Goldbach, 1990). Since these proteinases form part of the polyprotein, initial cleavages should be autocatalytic (see Figure lc).

The potyvirus group is one of the most important groups of plant viruses and members characteristically express their genome through a polyprotein process. The potyviral genome is approximately $10 \mathrm{~kb}$ in length and encodes a single polyprotein that is processed by three viral proteinases to yield nine or more mature proteins (Riechmann et al., 1992). Two of the proteinases, P1 and helper componentproteinase (HC-Pro), each catalyse cleavage only at their respective C termini (Verchot et al., 1991). The remaining cleavage sites (at least six) are processed by the Nla proteinase, a homologue of the picornaviral $3 C$ proteinase. This enzyme possesses a serinetype proteinase fold but contains a nudeophilic Cys residue rather than Ser at the active site (Gorbalenya et al., 1989).

The best known members of the group are tobacco etch virus (TEV) and potato $\mathrm{Y}$ virus (PVY). At present most is known 
about the gene products of TEV and their expression. Thus, the following sections deal mainly with this virus. The main features of the TEV genome are:(i) a VPg is attached to the $5^{\prime}$ end. (ii) a $5^{\prime}$ non-coding region of $144 \mathrm{nt}$ rich in $\mathrm{A}$ and $\mathrm{U}$; (iii) a single large ORF of 9161 nt initiating at residue 145-147, which could encode for a polyprotein with about 3000 amino acids (about $340 \mathrm{~K}$ ); and (iv) a 3' untranslated region of 190 bases terminating in a poly $(A)$ tract.

In the case of TEV the specificity of NIa is mediated by interaction between a binding site pocket around the active site and a heptapeptide motif, consisting of strictly and structurally conserved residues between the P6 and P1 positions of the cleavage site (Dougherty et al., 1989). Results of in vitro experiments indicate that processing sites flanking the $6 \mathrm{~K}$ protein and NIa are deaved preferentially in cis, whereas other sites are processed efficiently in trans (Carrington and Dougherty, 1988).

The $49 \mathrm{~K}$ N Ia protein is actually a polyprotein consisting of a proteinase domain $(27 \mathrm{~K})$ near the $\mathrm{C}$ terminus and a VPg (21 K) near the amino terminus (Dougherty and Parks, 1991). The VPg domain is attached covalently to the $5^{\prime}$ terminus of viral RNA via a phosphodiester linkage with Tyr-62 (Murphy et al., 1990). The N-terminal domain also contains a nudear localisation signal that directs the majority of NIa molecules to the nucleus of infected cells (Carrington et al., 1991).

Evidence indicates that NIa catalyses internal deavage at a rate much slower than that at other NIla-mediate cleavage sites, most likely as a result of a sub optimal context of the deavage site. While other N Ia-mediated cleavage sites in the TEV polyprotein contain conserved Tyr and Gln residues at the P3 and P1 positions, respectively, the internal NIa site contains Thr and Glu (Dougherty and Parks, 1991).

\section{Read-through protein}

The first cistron in the genomic viral RNA may have a "leaky" termination codon (UAG or a UGA) that can be suppressed by a host transfer RNA (tRNA), thereby permitting some of the ribosomes to read through into a downstream cistron as a result, giving rise a second longer functional polypeptide (see Figure 1a, Figure 1d.)

For the tobamoviruses, tobraviruses, tombusviruses, carmoviruses and for RNA1 of soilborne wheat mosaic furovirus (SBWMV), this read-through process allows synthesis of the putative polymerase, and for RNA2 of SBWMV, RNA1 of pea enation mosaic virus and the luteoviruses, the termination codon of the capsid protein gene is overcome to allow synthesis of a longer protein involved in transmission, virus assembly or other functions (Zaccomer et al., 1995).

The read-through process requires at least two elements. First, a suppressor tRNA; the nature of a possible candidate has been proposed for TMV (Beier et al., 1984;Zerfass and Beier, 1992a) and for tobacco rattle tobravirus (Zerfass and Beier, 1992b). Second, the nucleotide context surrounding the termination codon and in particular the two downstream codons appear important for readthrough of TMV RNA in vivo (Skuzeski et al., 1991) and in vitro (Valle et al., 1992)

\section{Translational frameshift}

Ribosomal frameshifting is a strategy frequently employed by various organisms to produce more than one protein from overlapping reading frames. It may occur in either direction.
A shift in the $3^{\prime}$ direction ( +1 frameshift) has been described in the yeast retrotransposon Ty (Belcourt and Farabaugh, 1990), whereas a shift in the $5^{\prime}$ direction (-1 frameshift) has been demostrated for retroviruses (Vickers and Ecker, 1992), luteoviruses (Prufer et al., 1992;García et al., 1993) and RCN MV (Xiong et al., 1993).

For a number of retroviruses, heptanudeotide signals are involved as "slippery sequences" in the frameshift. These include the sequences AAAAAAC (mouse mammary tumour virus); AAAUUUA (Rous sarcoma virus) and UUUUUUA (human immunoeficiency virus) which allow for tRNA slippage during translation (Hatfield et al., 1989). In addition to the specific sequence signal a second type of information bears relevance to frameshifting (Hatfield and Oroszlan, 1990): stem-loop structures immediately downstream of the "slippery sequences" have significant influence on the efficiency of the frameshift event.

Among plant RNA viruses, the RdRp of potato leafroll luteovirus (PLRV) is expressed by -1 ribosomal frameshifting in the region where the ORFs of the proteins $2 a$ and $2 b$ overlap. The viral genome of PLRV consists of $5.8 \mathrm{~kb}$ single stranded (+) RNA with six major ORFs (Mayo et al., 1989; Van der Wilk et al., 1989; Keese et al., 1990). An intergenic region located in the centre of the RNA genome separates a $5^{\prime}$ duster of genes (ORFs $1,2 \mathrm{a}$ and $2 \mathrm{~b}$ ), which are divergent among the luteoviruses sequenced so far, from a highly conserved gene block (ORFs 3,4 and 5 ) in the 3 ' half. In the 5' half of genomic PLRV RNA the small ORF1 is followed by two large ORFs, ORF2a and ORF2b, which may code for a $70 \mathrm{~K}$ and a $67 \mathrm{~K}$ protein, respectively, and contain the motifs characteristic of helicases (ORF2a and ORF2b; Habili and Symons, 1989) and GDD (ORF2b; Kamer an Argos, 1984).

The signal responsible for efficient frameshift in PLRV is composed of the slippery sequence UUUAAAU followed by a sequence that has the potential to adopt two alternative folding patterns, either a structure involving a pseudoknot, or a simple stem-loop structure. Kujawa et al. (1993) have confirmed that in PLRV-P (Polish isolate) the - 1 frameshift in the overlap region depends on the slippery site and on the downstream positioned sequence a proposed pseudoknot is required for efficient frameshifting. These results are in agreement with those reported for beet western yellows luteovirus by Garća et al. (1993).

Frameshifting has also been postulated as an expression strategy of PEMV RNA2 (Demler et al., 1993). Moreover, in beet yellows virus, a unique case among viruses of +1 frameshift has also been proposed (Agranovsky et al., 1994).

\section{Use of bicistronic RNAs}

A mechanism whereby the $5^{\prime}$ cistron was bypassed by ribosomes has been suggested for Agronowski (1991), cited by Hull (1992), for the expression of the beet yellows closterovirus $65-\mathrm{K}$ cistron, which is downstream of a $6.4-\mathrm{K}$ cistron. The latter cistron has no internal AUG codons in any of the reading frames, from where the expression of the 65-K cistron could be initiated. Recently, Grieco et al. (1995) has reported the presence of a bicistronic RNA from the olive latent virus 2. However, the RNA3 of the virus contains two clear-cut ORFs in same reading frame The encapsidation at a very low leve, of an RNA species (smaller by about $350 \mathrm{nt}$ and denominated RNA 4) with a very high sequence homology with the RNA3, could explain the expression of the second ORF. 
Gernemae RPA $5.677 \mathrm{mt}$
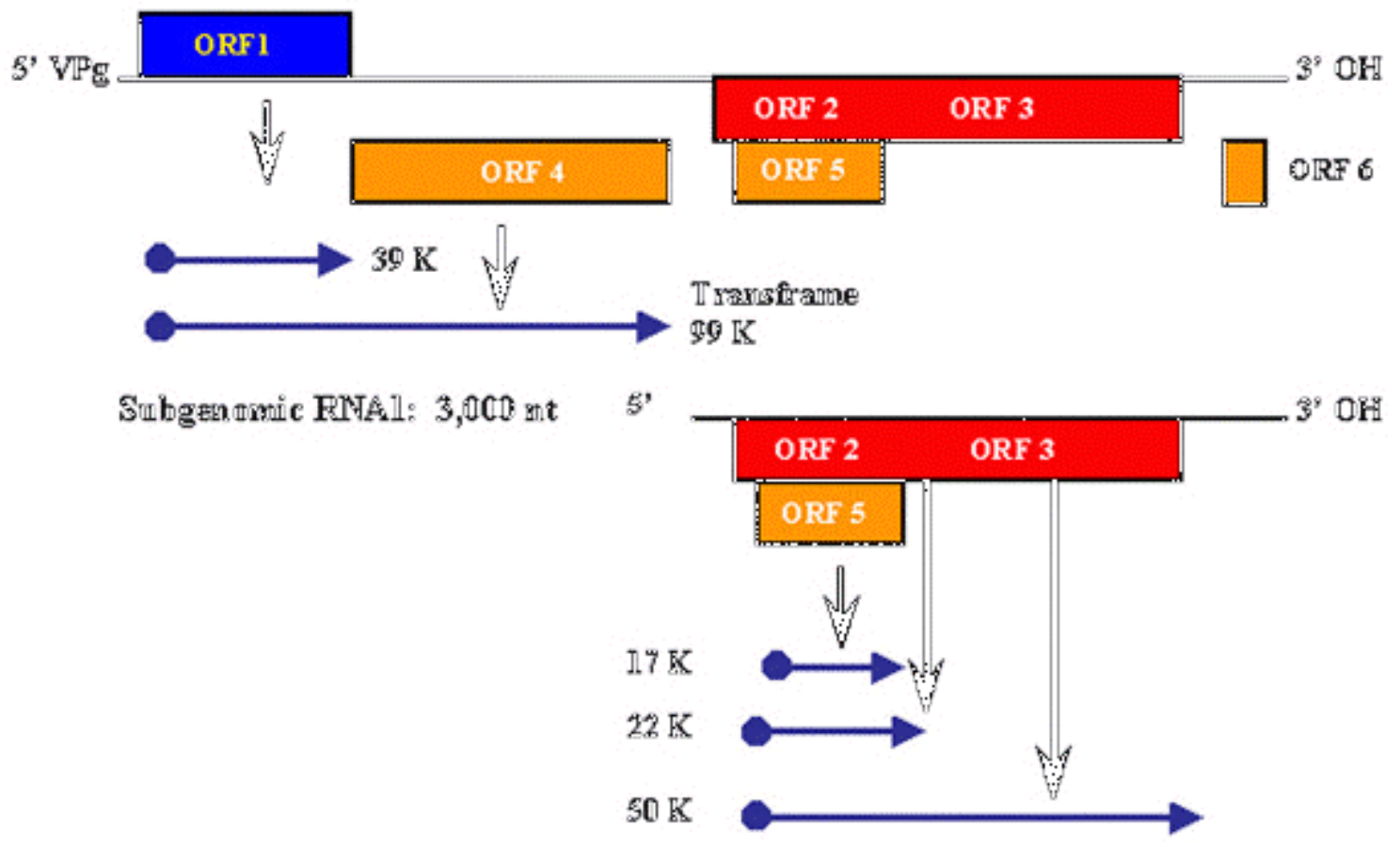

ONF 6

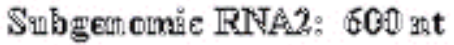

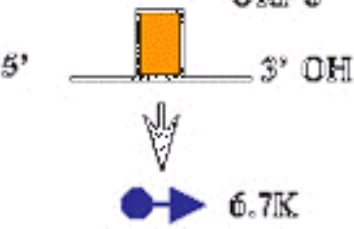

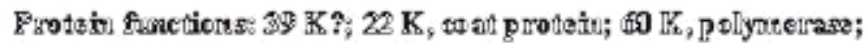

$17 \mathrm{YP}$ ? $; 50 \mathrm{~K}, ? ; 6.7 \mathrm{~K}$ ?, $90 \mathrm{~K}$ ?.

Or

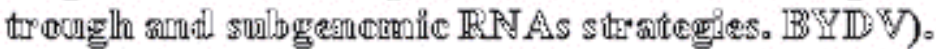

Figure 1d.

Three other mechanisms will be briefly mentioned here to explain the expression strategies used by caulimoflower mosaic virus (CaMV), a dsDNA virus that, to express the different cistrons, transcribes their genome into two RNA species, the polycistronic 35S and the monocistronic 195 (Rothnieet al., 1994; Kiss-Laszlo et al., 1995).

1.- "Ribosome shunt". Studies carried out to analyse the translation of the CaMV in protoplasts suggested a mechanism by which ribosomes enter at the cap site as normal and begin scanning. But at some point near the $5^{\prime}$ end of the leader, they are somehow transferred to a region at the $3^{\prime}$ end of the leader, without scanning linearly through the central portion of the leader. This process has been termed "ribosome shunt" and the sites between which it occurs have been defined (Futterer et al., 1993).

The shunt mechanism has been observed to operate between two separate RNA molecules, thus reinforcing the fact that the ribosomes are transferred directly from one part of the leader to another without scanning the sequence in between (Rothnie et al., 1994). 
2.- "Translational trans-activation". Translation of downstream ORFs on the polycistronic RNAS of caulimoviruses depends on the presence of a virally encoded translational trans-activator (TAV), which is the product of ORF VI. TAV is a complex protein that appears to be involved in many aspects of the virus life cycle (De Tapia et al., 1993 ). It has been shown to be part of abundant vacuolated inclusion bodies as well as determinant of host specificity and a factor influencing symptom development in infected plants (Broglio, 1995; De Tapia et al., 1993). As mention above, another of its role is to control translation from the polycistronic CaMV 35S RNA. Translational transactivation has been demonstrated for CaMV and figwort mosaic virus (Bonneville et al., 1989; Gowda et al., 1989) and appears to enhance expression of all the majors ORFs on the pregenomic 35S RNA (Scholthof et al., 1992). The TAV is itself translated from the 19S RNA, but can probably also trans-activated its own expression from ORF VI on the $35 S$ RNA (Driesen et al., 1993). Like the "ribosome shunt", transactivation seems to act on ribosomes that have begun scanning of the RNA at the $5^{\prime}$ end. The process of transactivation seems to allow ribosomes that have translated one ORF to remain competent to translate further downstream ORFS, or to become initiation competent once more (Rothnie et al., 1994).

3.- "Splicing". It was previously though that there was no obligate role for splicing in either plant or animal pararetroviruses. However, the finding of splicing in rice tungro bacilliform virus was the first case to break this rule (Futterer, 1994). More recently, Kiss-Laszlo et al. (1995) have described the detection of spliced CaMV RNAs in infected plants and transfected protoplasts. Transient expression experiments revealed a splice donor site in the leader sequence of CaMV $35 \mathrm{~S}$ RNA and three additional splice donor sites within ORF I. Splicing between the leader and ORF II produces an mRNA from which ORF III and, in the presence of TAV, ORF IV can be translated efficiently. The other three splicing events produce RNAs encoding ORF I-II in frame fusions. All four spliced CaMV RNAs were detected in CaMV-infected plants. Virus mutants in which the splice acceptor site in ORF II is inactivated are not infectious, indicating that splicing plays as essential role in the CaMV lifecycle.

These different strategies described above can be used exclusively, or, as a combination of strategies for a particular virus.

\section{References}

Adkins, S., Quadt, R., Choi, T. J., A hlquist, P., and German, T. (1995) An RNA-dependent RNA polymerase activity associated with virions of tomato spotted wilt virus, a plantand insect-infecting bunyavirus. Virology 207: 308-311.

Agranovsky, A. A., Koonin, E. V., Boyko, V. P., Maiss, E., Froetschl, R., Lunina, N. A., and Atabekov, J. G. (1994) Beet yellows dosterovirus: Complete genome structure and identification of a leader papain-like thiol protease. Virology 198: 311-324.

Ahlquist, P. (1992) Bromovirus RNA replication and transcription. Current Opinion in Genetics and Development 2: 71-76.

Ahlquist, P., Dasgupta, R., and Kaesberg, P. (1984) Nucleotide sequence of the brome mosaic virus genome and its implications for viral replication. Journal of Molecular Biology, 172, 369-384.

Allison, R.F., Janda, M. and Ahlquist, P. (1988) Infectious in vitro transcripts from cowpea chlorotic mottle virus CDNA clones and exchange of individual RNA components with brome mosaic virus. Journal of Virology, 62: 3581-3588.

Banerjee, A. (1987) Transcription and replication of rhabdovirus. Microbiological Reviews, 51: 66-87.

Barbier, P., Takahashi, M., Nakamura, I., Toriyama, S. and Ishihama, A. (1992) Solubilization and promoter analysis of RNA polymerase from rice stripe virus. Journal of Virology, 66: 6171-6174.

Bates, H.J., Farjah, M. Osman, T.A.M. and Buck, K.W.(1995) Isolation and characterization of an RNA-dependent RNA polymerase from Nicotiana develandii plants infected with red dover necrotic mosaic dianthovirus. Journal of General Virology, 76: 1483-1491.

Beier, H., Barciszewska, M., Krupp, G., Mitnacht, R., and Gross, H. J. (1984) UAG readt-hrough during TMV RNA translation: Isolation and sequence of two tRNAs super(Tyr) with suppressor activity from tobacco plants. EMBO Journal, 3: $351-356$

Belcourt, M. F., and Farabaugh, P. J. (1990) Ribosomal frameshifting in the yeast retrotransposon Ty: tRNA s induce slippage on a 7 nudeotide minimal site. Cell 62: 339-352. Bishop, D., Gay, M.E., and Matsuoko, Y. (1983) Nonviral heterogenous sequences are present at the $5^{\prime}$ ends of one species of snowshoe hare bunyavirus S complementary RNA. Nudeic Acids Research 11: 6409-6419.

Boccard, F., and Baulcombe, D. (1993) Mutational analysis of cis-acting sequence and gene function in RNA3 of cucumber mosaic virus. Virology 193: 563-578.

Bonneville, J. M., Sanfacon, H., Fuetterer, J., and Hohn, T. (1989) Posttranscriptional trans-activation in cauliflower mosaic virus. Cell 59: 1135-1143.

Bouloy, M., Pardigon, N., Vialat, P., Gerbaud, S., and Girard, M. (1990) 'Characterization of the 5 ' and 3 ' ends of viral messenger RNAs isolated from BHK21 cells infected with germiston virus (bunyavirus). Virology 175: 50-58.

Braam, J., UImanen, I., and Krug, R.M. (1983) Molecular model of a eucarytotic transcription complex: Functions and movements of influenza $P$ preoteins during capped RNAprimed transcription. Cell 34: 609-618.

Broglio, E.P. (1995) Mutational analysis of cauliflower mosaic-virus gene-VI-changes in host-range, symptoms, and discovery of transactivation-positive, noninfectious mutants. Molecular Plant-Microbe Interactions 8: 755-760.

Brunt, A., Crabtree, K., Dallwitz, Gibbs A., and Watson, L. (1996) Viruses of plants. Descriptions and lists from the VIDE database.CAB International.University Press, Cambridge , UK.

Bustamante, P. (1996) Molecular studies on Rice hoja blanca virus (RHBV). University of East Anglia. Ph.D. Thesis. 143pp.

Carrington, J.C., Freed, D.D., and Leinicke, A.J. (1991) Bipartite signal sequence mediate nud ear translocation of the plant potyviral Nla protein. Plant Cell 3: 953-962.

Carrington, and Dougherty, W. G. (1988) A viral deavage site casette: identification of amino acid sequences required for tobacco etch virus polyprotein processing. Proceedings of the National A cademy of Sciences USA 85: 3391-3395.

Conzelmann, K. K. (1996) Genetic manipulation of nonsegmented negative-strand RNA viruses. Journal of General Virology 77: 381-389. 
David, C., Gargouri-Bouzid, R. and Haenni, A. L (1992) RNA replication of plant viruses containing an RNA genome. Progress in Nudeic Acid Research and Molecular Biology 42: 157-227.

Dawson, W.O., P.Bubrick and G.L.Crantham (1988) Modifications of tobacco mosaic virus coat protein gene affecting replication, movement and symptomalogy. Phytopathology 78: 783.

Demler, S.A., Rucker, D. G, And Dezoeten, G. A. (1993) The chimeric nature of the genome of pea enation mosaic-virusthe independent replication of RNA-2. Journal of General Virology 74: 1-14.

Derssers, L., van der Krol, S., van Dermer,J., van Kammen and Zabel P. (1984) Purification of cowpea mosaic virus RNA replication complex: identification of a virus-encoded110,000dalton polypeptide responsible for RNA chain elongation. Proceedings of the National A cademy of Sciences USA. 81: 387-395.

De Tapia, M., Himmelbach, A., and Hohn, T. (1993) Molecular dissection of the cauliflower mosaic-virus translation transactivator. EMBO Journal 12: 3305-3314.

Dolja, V. V., and Carrington, J. C. (1992) Evolution of positive-strand RNA viruses. Seminars in Virology, 3: 315326.

Dougherty, W. G., and Parks, T. D. (1991) Post-translational processing of the tobacco etch virus 49-KDa small nuclear indusion polyprotein: Identification of an internal cleavage site and delimitation of VPg and proteinase domains. Virology 183: 449-456.

Dougherty, W. G., Parks, T.D., Cary, S.M., Bazan,J.F., and Fletterick, R. (1989) Characterisation of the catalytic residues of the tobacco etch virus $49-\mathrm{kDa}$ proteinase. Virology 172 : 302-310.

Driesen, M., Benito Moreno, R. M., Hohn, T., and Fuetterer, J. (1993) Transcription from the CaMV $19 \mathrm{~S}$ promoter and autocatalysis of translation from CaMV RNA. Virology 195: 203-210.

Eggen, R., Verver, J., Wellink, J., Pleu, K., van Kammen, A., and Goldbach, R. (1989) Analysis of sequences involved in cowpea mosaic virus RNA replication using site-specific mutants. Virology 173: 456-464.

French, R. and Ahlquist, P. (1987) Intercistronic as well as terminal sequences are required for efficient amplification of brome mosaic virus RNA 3. Journal of Virology 61: 1457-1465.

Futterer, J. (1994) Splicing in a plant pararetrovirus. Virology 198:663-670.

Futterer, J., Kiss Laszlo, Z., and Hohn, T. (1993) Nonlinear ribosome migration on cauliflower mosaic virus 35S RNA. Cell 73: 789-802.

Galinski, M.S. (1991) Paramyxoviridae-Transcrition and replication. Advances in Virus Research. 39: 129-162.

Garcia, A., Duin, J. and van Pleij, C. W. A. (1993) Differential response to frameshift signals in eukaryotic and prokaryotic translational systems. Nudeic Acids Research 21: 401-406.

German, T. L., Ullman, D. E., and Moyer, J. W. (1992) Tospoviruses: Diagnosis, molecular biology, phylogeny, and vector relationships. Annual Review of Phytopathology. 30:315-348
Goldbach, R. (1990) Plant viral proteinases. Seminars in Virology, 1: 335-346.

Goldbach R (1986) Molecular evolution of plant RNA viruses. Annual Review of Phytopathology. 24: 289-310.

Goldbach, R., Le Gall, O., and Wellink, J. (1991) Alpha-like viruses in plants. Seminars in Virology, 2; 19-25.

Gorbalenya, A. E., Koonin, E. V., Blinov, V. M., and Donchenko, A. P. (1988) Sobemovirus genome appears to encode a serine protease related to cysteine proteases of picornaviruses. FEBS Letters. 236: 287-290.

Gorbalenya, A. E., Koonin, E. V., Donchenko, A. P., and Blinov, V. M. (1989) Two related superfamilies of putative helicases involved in replication, recombination, repair and expression of DNA and RNA genomes. Nudeic Acids Research 17: 4713-4730.

Gowda, S., Wu, F. C., Scholthof, H. B., and Shepherd, R. J. (1989) Gene VI of figwort mosaic virus (caulimovirus group) functions in posttranscriptional expression of genes on the full-length RNA transcript. Proceedings of the National A cademy of Sciences USA. 86: 9203-9207.

Grieco, F., Martelli, G. P., and Savino, V. (1995) The nudeotide sequence of RNA3 and RNA4 of olive latent virus 2. Journal of General Virology 76: 929-937.

Gro, M. C., Di Bonito, P., Accardi, L., and Giorgi, C. (1992) Analysis of $3^{\prime}$ and $5^{\prime}$ ends of $\mathrm{N}$ and NSs messenger RNAs of toscana phlebovirus. Virology 191: 435-438.

Habili, N., and Symons, R. H. (1989) Evolutionary relationship between luteoviruses and other RNA plant viruses based on sequence motifs in their putative RNA polymerases and nucleic acid helicases. Nudeic Acids Research 17: 9543-9556.

Hamamatsu, C., Toriyama, S., Toyoda, T. and Ishihama, A. (1993) Ambisense coding strategy of the rice stripe virus genome: in vitro translation studies. Journal of General Virology 74: 1125-1131.

Hardy, S.F., German, T.L., Loesch-Fries, L.S., and Hall, T.C. (1979) Highly active template-specific RNA-dependent RNA polymerase from barley leaves infected with brome mosaic virus. Proceedings of the National A cademy of Sciences USA 76: 4956-4960.

Hatfield, D., and Oroszlan, S. (1990) The where, what and how of ribosomal frameshifting in retroviral protein synthesis. Trends in Biochemical Sciences 15: 186-190.

Hatfield, D., Feng, Y. X., Lee, B. J., Rein, A., Levin, J. G., and Oroszlan, S. (1989) Chromatographic analysis of the aminoacyl-tRNAs which are required for translation of codons at and around the ribosomal frameshift sites of HIV, HTLV-1, and BLV. Virology 173: 736-742.

Hayes, R. J., and Buck, K. W. (1990) Complete replication of a eukaryotic virus RNA in vitro by a purified RNA-dependent RNA polymerase Cell 63: 363-368.

Houwing C.J. and M.J.Jaspers (1986) Coat protein blocks the in vitro transcription of the virion RNAs of alfalfa mosaic virus. FEBS Letters. 209: 284

Huang, T. S., Palese, P., and Krystal, M. (1990) Determination of influenza virus proteins required for genome replication. Journal of Virology. 64: 5669-5673. 
Hull, R.(1994) Resistance to plant viruses: obtaining genes by non conventional approaches. Euphytica 75 195-205.

Hull, R. (1992) Report on the Federation of European Biochemical Societies Course on The Plant Virus Genome: structure and function, held at the Latvian Academy of Sciences, Riga, Latvia from April 30, 1991 to May 5, 1991. Virus Genes 6, 203-205.

Hull, R. (1990) Virus resistant plants: potential and risks. Chemistry and Industry London, pp. 543-546.

Hull, R., and Davies, J. W. (1992) Approaches to nonconventional control of plant virus diseases. Critical Reviews in Plant Sciences 11: 17-33.

Hsu MT, Parvin JD, Gupta S, Krystal M, Palese P. (1987) Genomic RNAs of influenza viruses are held in a circular conformation in virions and in infected cells by a terminal panhandle. Proceedings of the $\mathrm{N}$ ational Academy of Sciences USA. 84(22): 8140-8144.

Ishihama, A. and Barbier, P. (1994) Molecular anatomy of viral RNA-directed RNA polymerase. Archives of Virology. 134: 235-258.

Janda, M., and Ahlquist, P. (1993) RNA-dependent replication, transcription, and persistence of brome mosaic virus RNA replicons in S. cerevisiae. Cell 72: 961-970.

Jang, S.K., Krausslich, H. G., Nicklin, M. J. H, And Duke, G. M., Palmenberg, A. C. And Wimmer, E. (1988) A segment of the $5^{\prime}$ nontranslated region of encephalomyocarditis virusRNA directs internal entry of ribosomes during invitro translation. Journal of Virology 62: 2636-2643.

Jaspars, E.M.J., D.S. Gill, and R.H. Symmons (1985) Virology 144: 410.

Jin, H., and Elliott, R.M. (1993) Characterization of Bunyamwera virus S RNA that is transcribed and replicated by the $L$ protein expressed from recombinant vaccinia virus. Journal of Virology 67: 1396-1404.

Jin, H., and Elliott, R.M. (1991) Expression of functional Bunyamwera virus $L$ protein by recombinant vaccinia viruses. Journal of Virology 65: 4182-4189.

Kamer, G., and Argos, P. (1984) Primary structural comparison of RNA-dependent polymerases from plant, animal and bacterial viruses. Nucleic Acids Research 12: 7269-7282

Keese, P., Martin, R. R., Kawchuk, L. M., Waterhouse, P. M., and Gerlach, W. L. (1990) Nucleotide sequences of an Australian and a Canadian isolate of potato leafroll luteovirus and their relationships with two European isolates. Journal of General Virology, 71: 719-724.

Kiss-Laszlo, Z., Blanc, S., Hohn, T. (1995) Splicing of cauliflowerr mosaic vius $35 \mathrm{~S}$ RNA is essential for viral infectivity. EMBO Journal, 14: 3552-3556.

Kobayashi M, Tuchiya K, Nagata K, Ishihama A. (1992) Reconstitution of influenza virus RNA polymerase from three subunits expressed using recombinant baculovirus system. Virus Research. 22(3): 235-245.

Koonin, E. V. (1991a) The phylogeny of RNA-dependent RNA polymerases of positive-strand RNA viruses. Journal of General Virology. 72: 2197-2206.

Koonin, E. V. (1991b) Similarities in RNA helicases. Nature 352: 192
Koonin, E. V., and Dolja, V. V. (1993) Evolution and taxonomy of positive-strand RNA viruses: Implications of comparative analysis of amino acid sequences. Crc Critical Reviews in Biochemistry and Molecular Biology, 28: 375-430.

Koonin, E. V., Choi, G. H., Nuss, D. L., Shapira, R., and Carrington, J. C. (1991) Evidence for common ancestry of a chestnut blight hypovirulence-associated doublestranded RNA and a group of positive-strand RNA plant viruses. Proceedings of the Nattional A cademy of Sciences USA. 88: 10647-651.

Kormelink, R., de Haan, P., Peters, D., and Goldbach, R. (1992) Viral RNA synthesis in tomato spotted with virusinfected Nicotiana rustica plants. Journal of General Virology, 73: 687-693.

Kozak, M. (1991) Structural features in eukaryotic mRNAs that modulate the initiation of translation. Journal of Biological Chemistry, 266: 867-870.

Kroner, P. A., Young, B. M., and Ahlquist, P. (1990) A nalysis of the role of brome mosaic virus la protein domains in RNA replication, using linker insertion mutagenesis. Journal of Virology, 64: 6110-6120.

Kujawa, A. B., Drugeon, G., Hulanicka, D., and Haenni, A. L. (1993) Structural requirements for efficient translational frameshifting in the synthesis of the putative viral RNAdependent RNA polymerase of potato leafroll virus. Nucleic Acids Research, 21: 2165-2171.

Lahser, F. C., Marsh, L. E., and Hall, T. C. (1993) Contributions of the brome mosaic virus RNA-3 3'nontranslated region to replication and translation. Journal of Virology, 67: 3295-3303.

Lazarowitz, S. (1992) Geminiviruses: Genome structure and gene function. Critical Reviews on Plant Sciences, 11: 327-349.

Leathers, V., Tanguay, R., Kobayashi, M., and Gallie, D. R. (1993) A phylogenetically conserved sequence within viral $3^{\prime}$ untranslated RNA pseudoknots regulates translation. Molecular and Cellular Biology, 13: 5331-5347.

Lehto, K., and Dawson, W. O. (1990) Changing the start codon context of the 30K gene of tobacco mosaic virus from "weak" to "strong" does not increase expression. Virology 174: 169-176

Lommel, S. A., Weston Fina, M., Xiong, Z., and Lomonossoff, G. P. (1988) The nudeotide sequence and gene organization of red dover necrotic mosaic virus RNA-2. Nudeic Acids Research, 16: 8587-8602.

Mans, R. M. W., Steeg, M. H. v., Verlaan, P. W. G., Pleij, C. W. A., Bosch, L., and Van Steeg, M. H. (1992) Mutational analysis of the pseudoknot in the + RNA-like structure of turnip yellow mosaic virus RNA. A minoacylation efficiency and RNA pseudoknot stability. Journal of Molecular Biology, 223, $221-232$.

Marsh, L. E., Pogue, G. P., and Hall, T. C. (1989) Similarities among plant virus (+) and (-) RNA termini imply a common ancestry with promoters of eukaryotic tRNAs. Virology 172, 415-427.

Marsh, L.E., Dreher, T.W.and Hall, T.C. (1986) Analysis of the internal promotor for transcription of the subgenomic RNA4 of brome mosaic-virus. Journal of Cellular Biochemistry. S10d, p.289. 
Matthews, R. E. F. (1991) Plant Virology. 3rd Edition. Acad. Press. Inc.830 pp.

Mayo, M.A., Robinson, D.J., Jolly, C.A., and Hyman, L. (1989) Nucleotide sequence of potato leafroll luteovirus RNA. Journal of General Virology, 70: 1037-1051.

Meshi, T., Motoyoshi, F., Adachi, A., Watanabe, Y., Takamatsu, N., and Okada, Y. (1988) Two concomitant base substitutions in the putative replicase genes of tobacco mosaic virus confer the ability to overcome the effects of a tomato resistance gene, Tm-1. EMBO Journal, 7, 1575-1581.

Miller, W. A., and Hall, T. C. (1984) RNA-dependent RNA polymerase isolated from cowpea chlorotic mottle virusinfected cowpeas is specific for bromoviral RNA. Virology $132,53-60$

Miller, W. A., Dreher, T. W., and Hall, T. C. (1985) Synthesis of brome mosaic virus subgenomic RNA in vitro by internal initiation on (-)-sense genomic RNA. N ature 313, 68-70.

Mouches, C., Candresse, T., and Bove, J.M. (1984) Turnip yellow mosiac virus RNA-replicase contains host and virusencoded subunits. Virology 134: 78-90.

Murphy, F.A., Fauquet, C.M., Bishop, D.H.L., Ghabrial, S.A., Jarvis, A.W., Martelli, G.P., Mayo, M.A., and Summers, M.D. (eds.) (1995) Virus Taxonomy: Classification and Nomendature of Viruses. Springer-Verlag,Wien.

Murphy, J.F., Rhoades, R.E., Hunt, A.G., and Shaw, J.G. (1990) The VPg of tobacco etch virus RNA is the 49-kDa proteinase or the $\mathrm{N}$-terminal 24-kDa part of the proteinase. Virology 178: 285-288.

Nakagawa, Y., Kimura, N., Toyoda, T., Mizumoto, K., Ishihama, A., Oda, K. and Nakada, S. (1995) The RNA polymerase PB2 subunit is not required for replication of the influenza virus genome but is involved in capped mRNA synthesis. Journal of Virology, 69: 728-733.

Okamoto, S., Machida, Y., Takebe, I. (1988) Subcellularlocalization of tobacco mosaic-virus minus strand RNA in infected protoplasts. Virology. 167: 194-200.

Pelletier, J. and Sonenberg, N. (1988) Internal initiation of translation of eukaryotic mRNA directed by a sequence derived from poliovirus RNA. N ature 334 (6180): 320-325.

Palukaitis, P., Garcia Arenal, F, Sulzinski, M. A., and Zaitlin, M. (1983) Replication of tobacco mosaic-virus .7. Further characterization of singlestranded and doublestranded virus-related RNAs from TMV-infected plants. Virology. 131: 533-545.

Pogue, G. P., Marsh, L. E., Connell, J. P., and Hall, T. C. (1992) Requirement for ICR-like sequences in the replication of brome mosaic virus genomic RNA. Virology 188: 742-753.

Poole, T. L., Wang, C., Popp, R. A., Potgieter, L. N. D., Siddiqui, A., and Collett, M. S. (1995) Pestivirus translation initiation occurs by internal ribosome entry. Virology 206, 750-754.

Prüfer, D., Tacke, E., Schmitz, J., Kull, B., Kaufmann, A., and Rohde, W. (1992) Ribosomal frameshifting in plants: A novel signal directs the-1 frameshift in the synthesis of the putative viral replicase of potato leafroll luteovirus. EMBO Journal, 11: 1111-1117.

Quadt, R., Ishikawa, M., Janda, M., and Ahlquist, P. (1995) Formation of brome mosaic virus RNA-dependent RNA polymerase in yeast requires coexpression of viral proteins and viral RNA. Proceedings of the National Academy of Sciences USA 92: 4892-4896.

Quadt, R., Cheng Kao, C., Browning, K. S., Hershberger, R. P., and A hlquist, P. (1993) Characterization of a host protein associated with brome mosaic virus RNA-dependent RNA polymerase. Proceedings of the National. Academy of Sciences USA. 90: 1498-1502.

Quadt, R., and Jaspars, E. M. J. (1990) Purification and characterization of brome mosaic virus RNA-dependent RNA polymerase Virology 178, 189-194.

Ramirez, B. C., Garcin, D., Calvert, L. A., Kolakofsky, D., and Haenni, A. L. (1995) Capped nonviral sequences at the 5 ' end of the mRNAs of rice hoja blanca virus RNA4. Journal of Virology 69, 1951-1954.

Riechmann, J.L., Lain, S., Garcia, J.A. (1992) Highlights and prospects of potyvirus molecular-biology. Journal of General Virology, 73: 1-16.

Rothnie, H. M., Reid, J., and Hohn, T. (1994) Pararetrovirus and retroviruses: a comparative review of viral structure and gene expression strategies. Advances in Virus Research, 44: 1-67.

Rozanov, M. N., Koonin, E. V., and Gorbalenya, A. E. (1992) Conservation of the putative methyltransferase domain: A hallmark of the 'Sindbis-like' supergroup of positivestrand RNA viruses. Journal of General Virology, 73: 2129-2134.

Saito, T., Hosokawa, D., Meshi, T. And Okada, Y. (1987) Immunocytochemical localization of the $130 \mathrm{~K}$ and $180 \mathrm{k}$ proteins (putative replicase components) of tobacco mosaicvirus. Virology. 160: 477-481

Schmaljohn, C.S. (1996) Bunyaviridae: The viruses and their replication. In Fundamental Virology, Third Edition. Fields, B.N., Knipe, P.M., and Howley, P.M. (eds.). Lippincott Raven, Philadelphia. 1996. pp. 649-673.

Scholthof, H. B., Gowda, S., Wu, F. C., and Shepherd, R. J. (1992) The full-length transcript of a caulimovirus is a polycistronic mRNA whose genes are trans activated by the product of gene VI. Journal of Virology, 66: 3131-3139.

Shanks, M., Stanley, J. and Lomonossoff, G. P. (1986) The primary structure of red clover mottle virus middle component RNA. Virology. 155: 697-706.

Simons, J.F. and Pettersson, R.F. (1991) Host-derived 5' ends and overlapping complementary 3 ' ends of the two mRNAs transcribed from the ambisense $S$ segment of Uukuniemi virus. Journal of Virology. 65: 4741-4748.

Skuzeski, J.M., Nichols, L.M., Gesteland, R.F., and Atkins, J.F. (1991) The signal for a leaky UAG stop codon in several plant viruses indudes the two downstream codons. Journal of Molecular Biology, 218: 365-373.

Song, C. Z., and Simon, A. E. (1994) RNA-dependent RNA polymerase from plants infected with turnip crinkle virus can transcribe (+)- and (-)-strands of virus-associated RNAs. Procedings of the National Academy of Sciences USA 91: 8792-8796.

Strauss, E.G., Strauss, J.H., and Levine, A.J. (1996) Virus evolution. In Fundamental Virology, Third Edition. Fields, B.N., Knipe, P.M., and Howley, P.M. (eds.). Lippincott Raven, Philadelphia.1996. pp. 141-159. 
Symons, R. H. (1991) The intriguing viroids and virusoids what is their information- content and how did they evolve. Molecular Plant-M icrobe Interactions, 4: 111-121.

Takamatsu, N., Watanabe, Y., Meshi, T., and Okada, Y. (1990) Mutational analysis of the pseudoknot region in the $3^{\prime}$ noncoding region of tobacco mosaic virus RNA. Journal of Virology, 64, 3686-3693.

Timmermans, M., Das, O. and Messing, J. (1994) Geminiviruses and their uses as extrachromosomal replicons. Annual Review of Plant Physiology and Plant Molecular Biology 45: 79-112.

Toriyama, T. (1995) Genus Tenuivirus. In: Virus Taxonomy. Clasiffication and Nomenclature of viruses. (Murphy, F.A, et al. Eds). 1995. pp 316-318.

Traynor, P., Young, B. M., and Ahlquist, P. (1991) Deletion analysis of brome mosaic virus 2a protein: Effects on RNA replication and systemic spread. Journal of Virology, 65, 2807-2815.

Tsai, C. H., and Dreher, T. W. (1992) Second-site suppressor mutations assist in studying the function of the $3^{\prime}$ noncoding region of turnip yellow mosaic virus RNA. Journal of Virology, 66, 5190-5199.

Tsai, C. H., and Dreher, T. W. (1991) Turnip yellow mosaic virus RNA's with anticodon loop substitutions that result in decreased valylation fail to replicate efficiently. Journal of Virology, 65, 3060-3067.

Ulmanen, I., Seppala, P., and Pettersson, R.F. (1981) In vitro translation of Uukuniemi virus-specific RNAs: Identification of a nonstructural protein and a precursor to the membrane glycoproteins. Journal of Virology, 37: 72-79.

Vickers, T.A. and Ecker, D.J. (1992) Enhacement of ribosomal frameshifting by oligonudeotides targeted to the HIV gagpol region. Nucleic Adids Research, 20: 3945-3953

Valle, R. P. C., Drugeon, G., Devignes Morch, M. D., Legocki, A. B., and Haenni, A. L. (1992) Codon context effect in virus translational readthrough. A study in vitro of the determinants of TMV and Mo-MuLV amber suppression. FEBS Letters, 306, 2-3.

Van der Vossen, E.A.G., Neeleman, L., and Bot, J.F. (1993) Role of the 5 leader sequence of alfalfa mosaic virus RNA 3 in replication and translation of the viral RNA. Nucleic Acid Research, 21: 1361-1367.

Van der Wilk, F., Huisman, M.J., C.Cornelissen, B.J., Huttinga $H$. and Goldbach R. (1989) Nucleotide sequence and organization of potato leafroll virus genomic RNA. FEBS Letters, 245: 51-56.

Verchot, J., Koonin, E. V., and Carrington, J. C. (1991) The 35$\mathrm{kDa}$ protein from the $\mathrm{N}$-terminus of the potyviral polyprotein functions as a third virus-encoded proteinase. Virology 185: 527-535.

Vialat, P., and Bouloy, M. (1992) Germiston virus transcriptase requires active 405 ribosomal subunits and utilizes capped cellular RNAs. Journal of Virology, 66, 685693.

Xiong, Z., Kim, K. H., Kendal, T. L., and Lommel, S. A . (1993) Synthesis of the putative red clover necrotic mosaic virus RNA polymerase by ribosomal frame shifting in vitro. Virology 193: 213-221.

Young, N., Forney, J., and Zaitlin, M. (1987) Tobacco mosaic virus replicase and replicative structures. Journal of Cell Sciences. suppl. 7: 277-285.

Young, N., Palukaitis, P, And Zaitlin, M. (1985) RNA products of in vitro tobacco mosaic-virus replication. Phytopathology. 75: 1334.

Zaccomer, B., Haenni, A.-L., and Macaya, G. (1995) The remarkable variety of plant RNA virus genomes Journal of General Virology, 76: 231-247.

Zerfass, K. and Beier, H. (1992a) Pseudouridine in the anticodon GYA of plant cytoplasmic tRNATyr is required for UAG and UAA suppression in the TMV-specific context. Nucleic Acids Research, 20: 5911-5918.

Zerfass, K. and Beier, H. (1992b) The leaky UGA termination codon of tobacco rattle virus RNA is supressed by tobacco chloroplast and cytoplasmic tRNAsTrp with CmCA anticodon. EMBO Journal, 11: 4167-4173.

Zhao, X., Shaw, K and Cavanagh, D. (1993) Presence of subgenomic messenger-RNAs in virions of Coronavirus IBV. Virology

196:

$172-178$. 